\title{
Homofobia y ley penal: la homosexualidad como paradigma de peligrosidad social en el Derecho penal español (1933-1995)
}

\author{
Homophobia and criminal law: homosexuality as a paradigm of social dangerousness in \\ Spanish criminal law (1933-1995)
}

\author{
JUAN MARÍA TERRADILLOS BASOCO \\ Profesor Emértico. Catedrático de Derecho Penal \\ Universidad de Cádiz \\ juan.terradillos@uca.es \\ https://orcid.org/0000-0002-5361-3009
}

\begin{abstract}
Resumen: La Ley de Vagos y Maleantes (1933) constituye el primer tratamiento sistemático de la peligrosidad social en el Derecho español. Su vigencia se prolongó hasta 1970, en que fue sustituida por la Ley de Peligrosidad y Rehabilitación Social, vigente a su vez hasta 1995. Así, el concepto de peligrosidad social y sus consecuencias, las medidas de seguridad, tuvieron reconocimiento jurídicopositivo en tres regímenes políticamente incompatibles: República, dictadura franquista, democracia constitucional. Por encima de las diferencias de los sucesivos marcos normativos, la homosexualidad fue considerada paradigma de peligrosidad, y como tal fue definida, etiquetada y excluida. Cada modelo político aportó su propio argumentario ideológico, pero el resultado común fue -si es que no sigue siendo- la exclusión de un colectivo cuya única peligrosidad radicaba en el hecho de entender la autonomía sexual de modo distinto a los estereotipos hegemónicos en cada caso. Los mecanismos de disciplina y control se revistieron con ropajes jurídico-penales, pero la definición de su presupuesto nuclear -la peligrosidad- y la implementación del sistema sancionatorio -las medidas de seguridad- se asentaron siempre en principios incompatibles con los que caracterizan al Derecho penal democrático.
\end{abstract}

Abstract: The Ley de Vagos y Maleantes (1933) constitutes the first systematic treatment of social dangerousness in Spanish law. It remained in force until 1970, when it was replaced by the Ley de Peligrosidad y Rehabilitación Social, which remained in force until 1995. Thus, the concept of social dangerousness and its consequences, the safety measures, were legally and positively recognized in three politically incompatible regimes: the Republic, the Franco dictatorship and constitutional democracy. Beyond the differences of the successive normative frameworks, homosexuality was considered a paradigm of dangerousness, and as such was defined, labeled and excluded. Each political 
model contributed with its own ideological argument, but the common result was - if it isn't still- the exclusion of a collective whose only dangerousness lay in the fact of understanding sexual autonomy in a different way from the hegemonic stereotypes in each case. The mechanisms of discipline and control were dressed up in legal-criminal clothing, but the definition of their nuclear assumptiondangerousness - and the implementation of the sanctioning system - safety measures - were always based on principles that were incompatible with those that characterize democratic criminal law

Palabras claves: degradación moral, desviación, dictadura, homosexualidad, neuro-psiquiatría, peligrosidad social, política criminal excluyente.

Keywords: moral degradation, deviance, dictatorship, homosexuality, neuropsychiatry, social dangerousness, exclusionary criminal policy.

Sumario: INTRODUCCIÓN. 1. ESTIGMATIZACIÓN DE LA HOMOSEXUALIDAD. 1.1. Anomalía médico-psíquica. 1.2. Depravación moral. 1.3. Degradación política. 2. CRIMINALIZACIÓN DEL HOMOSEXUAL: LA PELIGROSIDAD. 2.1. El constructo ideológico. 2.2. El reflejo normativo. 2.2.A. Peligrosidad de la homosexualidad. 2.2.B. Peligrosidad por actos homosexuales. 3. DISCIPLINA Y CONTROL: LAS MEDIDAS DE SEGURIDAD. 3.1. Medidas. 3.2. Procedimientos. 3.3. Aplicación. 4. LA SUPERACIÓN CONSTITUCIONAL. 5. EPÍlLOGO. 6. BIBLIOGRAFÍA.

\section{INTRODUCCIÓN}

Los homosexuales entran en el ordenamiento punitivo español, como susceptibles de ser declarados en "estado peligroso", con la Ley de 15 de julio de 1954, reformadora de la Ley de Vagos y Maleantes, de 4 de agosto de 1933 (en adelante, LVM), quizá el corpus legal más representativo del modelo político-criminal de la II República.

Es la ley que dio carta de naturaleza en el ordenamiento español a las categorías "peligrosidad social", como presupuesto, y "medidas de seguridad", como consecuencia. Aunque la LVM no incluyó, expressis verbis, la homosexualidad en su inicial catálogo de supuestos de estado peligroso, la praxis policial y judicial no encontró demasiados obstáculos para imponer, aplicando criterios interpretativos de enorme laxitud, medidas de seguridad a los homosexuales como incursos en alguno de los apartados del art. $2^{\circ}$.

Es en esa praxis, en la posterior positivización de sus propuestas, en el argumentario aportado por las ciencias experimentales y, sobre todo, en la dialéctica erística del debate ideológico suscitado sobre la materia, donde se pueden rastrear los postulados rectores de los procesos de estigmatización (I), criminalización (II) y sanción (III) del homosexual.

\section{ESTIGMATIZACIÓN DE LA HOMOSEXUALIDAD}

El proceso de definición, a efectos político-criminales, de la homosexualidad, gestado en el tránsito del siglo XIX al XX, fue tributario de un fondo cultural histórico enraizado en el integrismo clerical, al que se sumaron elementos de estigmatización aportados por una medicina bio-eugenésica connivente con el poder y por las consignas victoriosas difundidas por dos 
dictaduras, encabezadas por los generales Primo de Rivera y Franco, para las que la seña de identidad de la españolidad era, especialmente para la segunda, "el machismo orgánico"1.

En ese marco, la homosexualidad no es considerada como una opción personal en materia sexual, sino como el peligroso precipitado de la degradación física, psíquica, moral y política que, según el discurso oficial de la postguerra, habría llegado a su zenit en el período republicano. Desde esa perspectiva se abordó la tarea no de conocer la homosexualidad, como dato ontológico, sino de connotarla negativamente, de estigmatizarla, en el plano definicionalvalorativo.

El acercamiento a la cuestión obliga, pues, al análisis tanto del objeto estigmatizado como de las características del poder etiquetador: las "imágenes turbadoras" asociadas al delito son creación de las agencias institucionales llamadas a afrontarlas, y, en reacción especular, "la existencia de las segundas se legitima solo con la existencia de las primeras" ${ }^{2}$.

\subsection{Anomalía médico-psíquica}

La conceptualización de la homosexualidad como estigma se aborda, en las primeras décadas del siglo XX, recurriendo a las metodologías propias de "la gran narración criminológica, según la cual se puede producir conformidad a través del tratamiento de la desviación" aceptaba, en efecto, el "modelo de transformación": como los efectos (incluidos crimen y criminal) tienen causas, es posible acabar con aquellos neutralizando estas. Y la tarea de identificar las causas determinantes de la homosexualidad se afronta, paradigmáticamente, desde la perspectiva científico-empírica, con criterios médicos.

Lo que supuso introducir en el análisis una conditio sine qua non de progreso, por cuanto el método científico requiere someter cada paso a la crítica, fundamentada en contrargumentos de la misma naturaleza (médica) que los de la argumentación. Tras los pasos del pre-galeno de la "Extracción de la piedra de la locura"4, se trataba no de aceptar la enfermedad como castigo divino, sino de identificar sus causas terrenales, para intentar ponerle remedio.

Ya en la segunda mitad del siglo XIX la pericia médica se había asegurado su presencia en el proceso penal, al que aportaba criterios de identificación y evaluación de los elementos determinantes de la inimputabilidad. Así había llegado a España el "alienismo", procedente de Francia, donde, de la mano de Esquirol, se había generalizado la utilización de conceptos biológicos y psiquiátricos en la justicia penal ${ }^{5}$. Y en el primer tercio del $\mathrm{XX}$, los sectores más

1 OLMEDA NICOLÁS, F., El látigo y la pluma, Editor Digital: Polifemo 7, Madrid, 2013, p. 30 (http://assets.espapdf.com, consulta: 21/05/2020).

${ }^{2}$ GALLO, E., y RUGGIERO, V., Il carcere immateriale, Edizioni Sonda, Torino, 1989, p. 134.

${ }^{3}$ DE GIORGI, A. Tolerancia cero: estrategias y prácticas de la sociedad de control, Virus Editorial, Barcelona, 2005, pp. 46-51.

4 TERRADILlOS BASOCO, J.M., Ensayos sobre arte y crimen, Tirant lo Blanch, Valencia, 2020, pp. 107-108.,

${ }^{5}$ FOUCAULT, M., Un caso de parricidio del siglo XIX presentado por Michel Foucault, Tusquets, Barcelona 
solventes de la neurología y de la psiquiatría -dinámicos investigadores y divulgadores de los avances científicos en materia de "perversiones sexuales"- pasaron de la superchería a la investigación, abandonando el plano mágico-religioso, en el que se venía radicando desde Job la enfermedad, para asentarse en el sistema científico.

Así, en 1966 era aplicable a España la constatación, reivindicada a nivel global por KRICH, de que, si bien con anterioridad se había venido considerando al homosexual "como una figura desvaída, hereditariamente corrompido y dominado por el vicio de una masturbación excesiva..., un libertino ahito, saciado de disipación heterosexual, hoy día, la homosexualidad se trata como sintoma" 6 .

No obstante, el éxito de la edición española de la obra colectiva Los homosexuales vistos por sí mismos y por sus médicos, con firmas como las de KRICH, FREUD, HISRSCHFELD o JUNG, no logró consolidar el axioma metodológico de que los análisis sobre la homosexualidad deberían situarse en el plano científico. De ello da prueba, en la introducción al volumen, el médico FRUTOS CARABIAS, que, revistiendo sus opiniones con la pátina del sicoanálisis, se despachaba contra la homosexualidad masculina -la femenina no importaba, ya que "la actividad sexual en la mujer no es, a menudo, necesaria"- calificándola de "relación sexual perversa", en la que siempre se detecta "un odio intenso... por el partenaire”, y en la que, a cada orgasmo, subsigue "una gran angustia, con miedo a la muerte y pánico a la condenación eterna" $"$.

La ubicación del debate en el seno de la ciencia médica, con ser un paso importante, no significó situarlo en un universo pacífico y valorativamente aséptico, ya que el estudio de la homosexualidad como expresión de conducta desviada o anormal, exige someterla a contraste con un modelo que responda a "lo normal, lo mayoritario, los valores aceptados", , es decir, con una referencia ideológica. De este modo, la cuestión sexual se constituye en objeto de los saberes médicos, progresivamente institucionalizados, pero integrada en el debate más general acerca de la salud colectiva, sobre el que, en la época, incide un poderoso elemento nacido en la incipiente biopolítica interventora: la medicina social, como "ciencia y regulación de las circunstancias patógenas medioambientales", que fue utilizada como sustento científico de las políticas eugenésicas ${ }^{9}$. El asesinato de Hildegart Rodríguez Carballeira por parte de su madre da cuenta de en qué medida las tesis eugenistas habían penetrado el tejido cultural de la II República ${ }^{10}$.

1976, p. 9.

${ }^{6}$ KRICH, A.M., "Prefacio" a Los homosexuales vistos por sí mismos y por sus médicos, (edit. Krich, A.M. ), Morata, Madrid, 1966, p. X.

${ }^{7}$ FRUTOS CARABIAS, L., "Introducción a la versión española", Los homosexuales vistos por sí mismos y por sus médicos (edit. Krich, A.M. ) Morata, Madrid, 1966, pp. 4-6.

${ }^{8}$ QUINTERO OLIVARES, G., Locos y culpables, Aranzadi, Pamplona, 1999, p. 32

${ }_{9}^{9}$ VÁZQUEZ GARCÍA, F.J., La invención del racismo. Nacimiento de la biopolítica en España 1600-1940, Akal, Madrid, 2009, pp. 203 y 210.

${ }^{10}$ Entre otras reconstrucciones históricas del hecho, ver DOMINGO, C., Mi querida hija Hildegart, Destino, 
La medicina y la psiquiatría de la época proyectan una imagen no homogénea de la homosexualidad.

Por un lado, es considerada característica innata, según las propuestas del influyente, en la época, HIRSCHFELD ${ }^{11}$, cuyo entendimiento de la homosexualidad como patología sexual de origen orgánico ${ }^{12}$ se aproxima a las construcciones del positivismo criminológico italiano, especialmente las de LOMBROSO, médico y, por ende, garante del saber científico ${ }^{13}$, que llevaron a sus colegas españoles a centrarse en el estudio de las diferencias somáticas entre sexos. Por otro lado, enfoques sociológicos, importados de la medicina social alemana ${ }^{14}$ y vinculables al positivismo criminológico de FERRI, fueron desarrollados en España por SALILLAS o BERNALDO DE QUIRÓS.

Pero serían las orientaciones psicológicas y psicoanalistas las que, desde una posición dominante, vendrían a completar el andamiaje de los estudios "científicos" sobre la homosexualidad.

GREGORIO MARAÑÓN Y POSADILLO, en este período la figura más reconocida, encabezó la orientación cientificista y, en esa medida, humanitaria. A espaldas de la extendida afición a la descalificación ética o a la condena jurídica, prefirió orientar su trabajo hacia la explicación de "la transgresión de los homosexuales" a partir de "la posibilidad de una indiferenciación del instinto" 15 .

En torno a los años veinte, MARAÑÓN, profundo conocedor de la psicología y el psicoanálisis norteamericanos y europeos del momento, formuló todo un sistema teórico explicativo de los estados sexuales, tomando como base, sin desdeñar in totum la eficacia etiológica del entorno, sus estudios endocrinológicos, que le llevan, en coincidencia parcial con FREUD, a la consideración de la homosexualidad como producto de la insuficiente diferenciación sexual: "la intersexualidad es una fase obligada y pasajera-aunque no siempre definitivamente pasajera- de la evolución normal; en tanto que la homosexualidad es un episodio aberrante de esa evolución... El homosexual es simplemente el hijo de un extravio evolutivo. No es un

Barcelona, 2008. FERNÁN GÓMEZ, F., dirigió el film Mi hija Hildegart, y GRANDES, A., noveló la vida de Aurora Rodríguez, en La madre de Franknestein, Tusquets, Barcelona, 2020.

${ }^{11}$ HIRSCHFELD, M., "El homosexual como sexo intermedio", en Los homosexuales vistos por sí mismos y por sus médicos, (edit. Krich, A.M.) Morata, Madrid, 1966, p. 177.

12 JIMÉNEZ DE ASÚA, L., "Epílogo”, a HERNÁNDEZ-CATÁ, A., El Ángel de Sodoma, 2a ed., Mundo Latino, Madrid, 1929, p. 243.

${ }_{13}$ MARISTANY, L., El gabinete del doctor Lombroso (Delincuencia y fin de siglo en España), Anagrama, Barcelona, Madrid, 1973, p. 31.

${ }^{14}$ VÁZQUEZ GARCÍA, F.J., La invención del racismo. Nacimiento de la biopolítica en España 1600-1940, op. cit. p. 208.

15 PINILlOS, J.L., "Marañón, transgresor de su época", en La evolución de la sexualidad y los estados intersexuales, (edit. Botella Llusiá, J., y Fernández de Molina, A.), Ediciones Díaz de Santos, Madrid, 1997, p. 62. 
enfermo ni un monstruo, ni tampoco un delincuente, aun cuando pueda delinquir como el individuo de sexo más perfecto" $"$.

La consecuencia político-criminal es obvia: "las anomalías del sexo no se combaten extirpándolas por la violencia, sino cegando la fuente que las origina" ${ }^{17}$. Cualquier forma de criminalización es no solo, en el plano científico, "una insensatez", sino también, en el social, "una táctica a más de inhumana, notoriamente contraproducente" 18 , pues lo que se requiere son terapias dirigidas a superar la indiferenciación sexual. Si la homosexualidad es, como la diabetes, una anormalidad que en absoluto se vincula al crimen, compete a la sociedad no castigar penalmente, sino intentar rectificar el instinto "torcido", recurriendo a la medicina 19 .

Incidiría en la materia SANCHIS BANÚS, fautor, con JIMÉNEZ DE ASÚA de la fórmula de inimputabilidad acorde con las "concepciones de la psiquiatría moderna" ${ }^{20}$ recogida en el Código Penal (en adelante, CP) de 1932: "el enajenado y el que se halle en situación de trastorno mental transitorio". A propósito de la homosexualidad, el psiquiatra mantiene que el proceso predominante en la producción de las neurosis "no es la libido, sino la represión del instinto sexual ejercida por la censura y favorecida por la educación". En consecuencia, el homosexual solo podrá evitar las inclinaciones mórbidas cuando haya superado todas las fases del desarrollo sexual que concluye en la heterosexualidad ${ }^{21}$.

Estos aportes de origen médico-psiquiátrico ratifican, en buena medida, las propuestas políticocriminales más generales adelantadas cincuenta años antes por el krausismo, que había hecho suya la aportación de RÖDER de que la intervención penal ha de tener por objetivo, en lugar de reprimir, aportar medios racionales y necesarios para "ayudar á la voluntad, injustamente determinada, de un miembro del Estado, á ordenarse por sí misma"22.

La inmediata consecuencia es, como hiciera el correccionalismo, sobre todo el de DORADO MONTERO, hacer de la intervención penal una providencia útil y amable, más terapia que castigo $^{23}$. Las investigaciones criminológicas de SALDAÑA en materia de sexualidad,

\footnotetext{
${ }^{16}$ MARAÑÓN, G., "Prólogo" a HERNÁnDEZ-CATÁ, A., El Ángel de Sodoma, $2^{\mathrm{a}}$ ed., Mundo Latino, Madrid, 1929 , p. 32.

${ }^{17}$ MARAÑÓN, G., "Prólogo", op. cit., pp. 29-30.

${ }^{18}$ MARAÑÓN, G., La evolución de la sexualidad y los estados intersexuales, Ediciones Arcos, Madrid, 1951, p. 129.

${ }^{19}$ MARAÑÓN, G., Los estados intersexuales en la especie humana, Javier Morata, Madrid, 1929, p. 127.

${ }^{20}$ Código Penal de 1932, Exposición de Motivos. V.

${ }^{21}$ PÉREZ SALMÓN, C., "Sanchís Banús y el psicoanálisis: historia de una relación", en Revista de Historia de la Psicología, 3-4, 2003, p. 522.

22 RÖDER, C.D.A., Las doctrinas fundamentales reinantes sobre el delito y la pena en sus interiores contradicciones. Ensayo crítico preparatorio para la renovación del Derecho Penal, $3^{\mathrm{a}}$ ed., Librería de Victoriano Suárez, Madrid, 1876, p. 344.

${ }^{23}$ TERRADILLOS BASOCO, J.M., "Vigencia del derecho penal del krausismo", en AA.VV., Jornadas Homenaje a Giner de los Ríos, Universidad de Jaén, Jaén, 1999, p. 44.
} 
desarrolladas sobre todo en La Sexología: ensayos (1930), vinieron a concretar la estrategia frente a la anormalidad sexual: lo procedente no son las penas del CP de 1928, sino medidas de seguridad adecuadas al caso, por ejemplo, tratamiento psiquiátrico en establecimientos adecuados.

En dirección bien contraria a la de la investigación, en sus distintas vertientes, otros, intentaron, simplemente, encubrir la superchería o la descalificación moral con el oropel de lo científico.

A este objetivo se plegó el discurso pseudo-médico de NAVARRO FERNÁNDEZ, psiquiatra y savonarola de burdeles, que, ya en los prolegómenos de la dictadura de Primo de Rivera, había implementado una campaña "sanitaria" contra las manifestaciones de homosexualidad, peligro grave para el modelo de hombre nuevo, tan reivindicado - en cuanto "conquista del verdadero humanismo, propia de la civilización cristiana" ${ }^{24}$ - por los corifeos de la dictadura ${ }^{25}$.

En aval de conclusiones igualmente inocuizadoras, VALLEJO NÁGERA, médico que llegaría a dirigir los Servicios Psiquiátricos del Ejército franquista, pergeñó el andamiaje "científico" al discurso racista oficial del régimen sobre las bases de las doctrinas alemanas de la "biología criminal" 26 , que le permitieron identificar las íntimas relaciones entre marxismo y enfermedad mental y abrazar las políticas eugenésicas aplicadas por el nazismo a los homosexuales ${ }^{27}$. De ahí surgió su propuesta más definitoria: la asexualización de los psicópatas -título de su conocida publicación de 1934-, que, en el caso de los psicópatas sexuales, habría de revestir la forma de esterilización, medida eugenésica idónea para "infanticidas, violadores, homosexuales y pervertidos de todas las categorías, de manera que, en realidad, pierde poco la sociedad al privar del derecho de la paternidad a tales desechos de presidio"28.

La tarea inocuizadora es confiada por el psiquiatra que llegó a ser conocido como el "Mengele español" no a los médicos ni a los biólogos, sino a los juristas ${ }^{29}$. La propuesta, aparentemente contradictoria viniendo de un psiquiatra, es, sin embargo, coherente. Los homosexuales y los pervertidos, a diferencia de violadores o infanticidas, quedan definidos no por sus hechos, como matar bebés o violar, sino por su condición personal: la perversión, etiqueta más moral que

\footnotetext{
${ }^{24}$ PEMÁN, J. M, El hecho y la idea de la Unión Patriótica, Imprenta Artística Sáez Hermanos, Madrid, 1929, p. 184.

25 CLEMINSON, R., "Marginados dentro de la marginación: prostitución masculina e historiografía de la sexualidad (España, 1880-1930)" en Las figuras del desorden. Heterodoxos, proscritos y marginados. Actas del V Congreso de Historia Social de España, (coord. Castillo, S., y Oliver, P.), Siglo XXI, Madrid, 2006, pp. 326328.

26 TERRADILlOS BASOCO, J.M., “Construcción y enseñanza del Derecho penal del Nuevo Estado. Los orígenes del Código Penal de 1944”, en Modelos de Derecho del Trabajo y cultura de los juristas, (coord. Baylos Grau, A.), Bomarzo, Albacete, 2014, p. 207.

${ }^{27}$ MUÑOZ CONDE, F., Edmund Mezger y el Derecho penal de su tiempo, $4^{\mathrm{a}}$ ed., Tirant lo Blanch, Valencia, 2003, pp. 252 у 271.

${ }^{28}$ VALLEJO NÁGERA, A., La asexualización de los psicópatas, Medicina, Madrid, 1934, p. 89.

${ }^{29}$ VALLEJO NÁGERA, A., La asexualización de los psicópatas, op. cit., p. 89.
} 
psíquica, que les convierte en criminalmente peligrosos, ha de ser afrontada por el Derecho punitivo y no por la medicina ${ }^{30}$.

Más tarde, LÓPEZ IBOR, a partir de 1957, desarrollaría sus propuestas de considerar a la homosexualidad como una modalidad de perversión, opuesta a la normalidad ética, entendida como arquetipo ideal, no en sentido estadístico sino valorativo ${ }^{31}$. Y en 1968, el año del mayo francés o la primavera de Praga, publicaría El libro de la vida sexual, en el que, desde su perspectiva psiquiátrica, defendía que el homosexual es más enfermo que delincuente; a pesar de lo que no elude aplicarle etiquetas morales descalificantes: el coito anal, por ejemplo, solo es concebible entre "individuos muy degenerados éticamente"32.

Se cierra así el círculo vicioso de la estigmatización médica de la homosexualidad: de la neurología y la psiquiatría, que pretenden servirse de una metodología científica, se regresa a la descalificación moral y política, delegando en la ideología la construcción de los criterios de identificación del homosexual $\mathrm{y}$, en consecuencia, de los medios a utilizar en su curación/eliminación.

\subsection{Depravación moral}

La vieja convicción, viva desde la España barroca, de que "el sodomita, interrumpe el orden natural establecido por Dios, donde los humanos deben propagar su fe mediante su propia reproducción" 33 , ha permanecido en el tiempo. Y todavía a principios del siglo XX, BERNALDO DE QUIRÓS podía dejar constancia de la hostilidad que la población patria desplegaba frente a las repugnantes prácticas homosexuales ${ }^{34}$.

Con todo, conviene no incurrir en la simplificación, tantas veces interesada, de identificar la parte con el todo. La valoración social no era monolítica: se mostraba más tolerante en las grandes ciudades -en las que "la ideología del bloque dominante había perdido su función hegemónica" "35 -, y más inquisitorial en los núcleos rurales o en ciudades menores, donde seguían imponiendo sus códigos morales el clero y el funcionariado.

Respecto al primero, hay que recordar que la simbiosis entre Iglesia católica y franquismo fue "absoluta", de modo que el nacionalcatolicismo "inspiró la protección penal de una determinada moral sexual y la tradicional discriminación de la mujer y de la

\footnotetext{
${ }^{30}$ TERRADILLOS BASOCO, J.M., Ensayos sobre arte y crimen, op. cit., p. 81.

${ }^{31}$ MORA GASPAR, V., Al margen de la naturaleza. La persecución de la homosexualidad durante el franquismo. Leyes, terapias y condenas, Debate, Barcelona, 2016, pp. 68-69.

${ }^{32}$ LÓPEZ IBOR, J. J., El libro de la vida sexual, Danae, Barcelona, 1968, p. 568.

33 TOMÁS Y VALIENTE, F., "El crimen y el pecado contra natura", en Orientaciones. Revista de homosexualidades, 1, 2001, p. 109.

${ }^{34}$ BERNALdo DE QUiRÓS, C., y LlanAS AGUINALEDO, J. Ma , La Mala Vida en Madrid. Estudio psicosociológico, B. Rodríguez Sierra, Madrid, 1901, p. 283
}

35 TUÑÓN DE LARA, M., La II República.1, Siglo XXI, Madrid, 1976, pp. 13-14. 
homosexualidad"36. En cuanto al funcionariado, exprimió las posibilidades de utilizar la satanización de la homosexualidad para consolidar y fortalecer un modelo de ciudadanía civil coherente con las características del caballero católico.

El estigma moral no procedía, sin embargo, solo del integrismo político o religioso. Los programas de educación del cuerpo y de la salud propios del regeneracionismo -en sus múltiples $\mathrm{y}$, en muchas ocasiones, no homologables vertientes-, le habían allanado el camino.

Así, la Institución Libre de Enseñanza, que asumió los objetivos de regeneración desde una perspectiva progresiva, asignó a la escuela, y no a la familia escasamente formada, el deber de promocionar, en régimen de coeducación, el ejercicio físico y el acercamiento a la naturaleza. Tanto el cuerpo como los afectos, las emociones y la voluntad se constituyen en blancos prioritarios de la acción pedagógica, dirigida, en palabras de COSSÍO, a "crear sujetos vigorosos de cuerpo y alma, cultos y varoniles" ${ }^{37}$.

La entronización de la virilidad como modelo se corresponde, en efecto, con el difuso anhelo regeneracionista de "producción" de un nuevo tipo de español, libre de la degeneración histórica que tan nefastas consecuencias había acarreado al país. "Fuera sensible -se lamenta un obsceno DE MAEZTU- que estos preciosos síntomas de renacimiento quedáran reducidos á débiles gritos vaginales, faltos de un cerebro poderoso que supiera hacer de ellos la fortísima voz de una nación"38.

Se ha imputado al regeneracionismo que, en alguna de sus vertientes, para llevar adelante su propósito de "limpieza de la cultura y la raza españolas", se decantara "por destilar un odio especifico muy sanguinario hacia la homosexualidad"39. La tacha solo está justificada si referida a los sectores del heterogéneo movimiento regeneracionista que buscaron el origen de la decadencia nacional en el plano sexual, centrados en una tan miope como limitadora obsesión por la virilidad perdida.

La recuperación regeneracionista de la masculinidad, propia del hombre nuevo -antecedente tanto del uomo nuovo mussoliniano ${ }^{40}$ como del primoriverista- y crisol de las esencias

\footnotetext{
${ }^{36}$ PORTILLA CONTRERAS, G., "Colaboración de la Iglesia católica en la represión penal de la masonería y el comunismo durante el franquismo”, en Revista Penal. México, 3, 2012, pp. 193-195.

${ }^{37}$ VÁZQUEZ GARCÍA, F.J., y CLEMINSON, R., Los invisibles. Una historia de la homosexualidad masculina en España, 1850-1939, Comares, Granada, 2011, p. 155.

38 DE MAEZTU, R., Hacia otra España, Imp. y Enc. de Andrés P. Cardenal, Bilbao, 1989, p. 233. (http://www.memoriadigitalvasca.es/handle/10357/5225, consulta: 21/05/2020).

${ }^{39}$ MORA GASPAR, V., Al margen de la naturaleza. La persecución de la homosexualidad durante el franquismo. Leyes, terapias y condenas, op. cit., p.26.

${ }^{40}$ QUIROGA FERNÁNDEZ DE SOTO, A., "Educación para la ciudadanía autoritaria. La nacionalización de los jóvenes en la dictadura de Primo de Rivera", en Historia de la Educación. Revista Interuniversitaria, 27, 2008, p. 92.
} 
españolas, exige una implicación activa de toda la sociedad frente a la degradación representada por el "moro", asociado a la sodomía, y el anarquista, proclive al afeminamiento ${ }^{41}$.

Y así, la criminalización en el CP de 1928 -el del general Primo de Rivera- de la homosexualidad, tan detestada por la derecha política como la pornografía, "arma certera -en valoración de PEMÁN- de infalible acierto psicológico, para minar por su cimiento familiar todo el orden social"42, respondía a la retórica regeneracionista que exigía poner freno a la decadencia nacional, actuando contundentemente sobre la cuestión sexual.

El régimen surgido de la guerra civil heredaría y potenciaría la entronización de esa virilidad, con la consiguiente postergación de las mujeres, "esas madres cristianas que trajeron al mundo a los alféreces provisionales", instrumento al servicio del macho, como teorizara Enrique HERRERA ORIA ${ }^{43}$. Lo que tuvo como consecuencia la diferenciación valorativa entre dos presuntas modalidades de homosexualidad: el afeminado que la ejercía de forma pasiva era considerado invertido, depravado o incluso peligroso, según el plano -médico, moral, jurídicoen el que se situara el sujeto estigmatizante. Y se tachaba de pervertido -pero no de anormal- al que practicaba la sodomía de forma activa, manteniendo su estatus de masculinidad ${ }^{44}$.

\subsection{Degradación política}

La "inversión” sexual es contagiosa y, por tanto, peligrosa, pero no solo para la salud: también para la paz ciudadana, por su vinculación con el crimen, insistentemente pregonada por los medios más influyentes de la derecha política. Lo que impone que debe ser afrontada, sobre todo, desde el control policial y penal.

La construcción del homosexual incorpora, así, otro elemento: a su condición de pervertido y/o anormal y a su aberrante integración en el "sexo débil", se añade la descalificación por el sustrato político en el que nace y crece.

El lapso de tiempo que va desde la debacle de 1898 hasta la consolidación del franquismo en la postguerra registra los anhelos oficialistas por reinstaurar los perfiles de la virilidad como antídoto a la degeneración colectiva que todos -de regeneracionistas a fascistas- denuncian y combaten. Con la consiguiente etiquetación del homosexual desde las trincheras políticas, en las que se le cuelga el sambenito de enemigo.

La propuesta cuenta con antecedentes en el pensamiento peligrosista, por ejemplo en los análisis lombrosianos de fines del XIX, "que alineaban en un mismo recinto, el de la psicología

\footnotetext{
${ }^{41}$ QUIROGA FERNÁNDEZ DE SOTO, A., Haciendo españoles: la nacionalización de las masas en la Dictadura de Primo de Rivera (1923-1930), Centro de Estudios Políticos y Constitucionales, Madrid, 2008, p. 270.

42 PEMÁN, J. Mª El hecho y la idea de la Unión Patriótica, op. cit., p. 218.

${ }^{43}$ HERRERA ORIA, E., Historia de la Educación Española desde el Renacimiento, Veritas, Madrid, 1941, pp. 490 y $436-439$.

${ }^{44}$ MORA GASPAR, V., Al margen de la naturaleza. La persecución de la homosexualidad durante el franquismo. Leyes, terapias y condenas, op. cit. pp.38-39.
} 
morbosa y anormal, al hombre criminal, al loco, al desequilibrado y al neurótico, al revolucionario anarquista y al mismísimo creador u hombre de genio" 45 .

Atribuir peligrosidad al disidente político -enemigo, en los regímenes totalitarios- no es, pues, novedoso. Y enemigo ha de ser, forzosamente, quien encarna los rasgos convencionales de la feminidad y, por ende, alimenta el declive de la virilidad patria.

Para detenerlo, la Unión Patriótica, el partido único en la dictadura de Primo de Rivera, que había recuperado algunas asociaciones reaccionarias ya periclitadas, como las Juntas de Defensa, e incorporado otras nacidas al socaire del pronunciamiento militar de 1923, asumió la tarea de extender e imponer la integración nacional en torno a los nuevos valores, objetivo que define al partido: "la Unión Patriótica es una 'conducta organizada'; pero una conducta, ha explicado muchas veces su Jefe nacional, social, ciudadana, apolítica" "46.

La labor de adoctrinamiento desplegada pasaba, además de por la censura de la prensa, por la de la enseñanza, "que debe ser formación y moldeamiento espiritual que tiende a la formación, como dice Ortega y Gasset de un tipo ideal de hombre. Y el tipo ideal de hombre español, dotado de un sentido superior de solidaridad, que la enseñanza patria debe formar con afán, no puede lograrse sin cultura y formación religiosa" 47 .

Y cuando la enseñanza, teleológicamente dirigida, no haya logrado imponer ese tipo ideal, "la Raza precisa privar a los indeseables de los derechos ciudadanos mientras no se hayan regenerado mediante la reeducación "48. Hasta tanto se corone con éxito el taumatúrgico procedimiento, los indeseables quedan excluidos de la titularidad de derechos, en aras, claro, de la "Raza".

Especialmente compete a la Universidad española -de la que queda excluida la mujer, que "debe ocuparse de los trabajos de casa y prepararse para su futura misión de madre"49- la formación de "los millares de intelectuales hispánicos que están llamados a difundir la esencia del espíritu español a más de cien millones de hombres que hablan la lengua calificada por Carlos V de única digna de hablar con Dios" $" 50$.

No se consiguió llevar la esencia de lo español a tan amplias capas de población foránea. Y tampoco se consiguió salir del analfabetismo, que afectaba, entre el 30 y el 40\%, a la población

\footnotetext{
${ }^{45}$ MARISTANY, L., El gabinete del doctor Lombroso (Delincuencia y fin de siglo en España), op. cit., p. 14.

${ }^{46}$ PEMÁN, J. Mª, El hecho y la idea de la Unión Patriótica, op. cit., p. 67.

${ }^{47}$ PEMÁN, J. Ma, El hecho y la idea de la Unión Patriótica, op. cit., pp. 312-313.

${ }^{48}$ VALLEJO NÁGERA, A., Eugenesia de la Hispanidad y regeneración de la raza, Editorial Española, Burgos, 1937, p. 129.

${ }^{49}$ HERRERA ORIA, E., Historia de la Educación Española desde el Renacimiento, op. cit., p. 437.

50 PEMARTíN, J., Los valores históricos de la Dictadura española, $2^{\mathrm{a}}$ ed., Publicaciones de la Junta de Propaganda Patriótica y Ciudadana, Madrid, 1929, p. 448.
} 
española ${ }^{51}$, convirtiéndola en dócil receptor de los mensajes simplificadores, siempre orientados a neutralizar los problemas sociales mediante la identificación y expiación de un enemigo, el otro, el distinto, fácilmente satanizable.

En su fase franquista, la aplicación de la LVM estuvo también sustentada en un inmenso aparato de propaganda dirigido a consolidar los mismos paradigmas vacuos -macho de acendrada hombría, mitad monje-mitad soldado, patriota y heredero de un imperio, de inmaculada raza y dogmas paleocristianos-, incompatibles todos ellos con la condición homosexual. Frente al "mimetismo extranjerizante, la rusofilia y el afeminamiento... " el régimen iba a oponer "el viril heroísmo de la juventud en acción, que tan generosa sangre derrama en el frente por el rescate definitivo de la auténtica cultura española" 52 .

La virilidad es valor que no germina en el bando republicano, tal como obscenamente, proclamara QUEIPO DE LLANO, uno de los generales vencedores de la contienda civil: "Nuestros valientes legionarios y regulares han enseñado a los rojos lo que es ser hombre. De paso también a las mujeres de los rojos, que ahora por fin han conocido hombres de verdad, y no castrados milicianos. Dar patadas y berrear no las salvará" 53.

El franquismo, que no había desperdiciado las posibilidades de estigmatización del homosexual como enfermo o inmoral ${ }^{54}$, avanzó también en la línea política de exclusión: una vez reducido el mundo político a la tensión bélica amigo-enemigo, identificado aquel con los valores del Movimiento, y este con la herencia del bolchevismo y de sus temblorosos aliados burgueses, el homosexual solo podía germinar en este segundo bando. Así lo sintetiza CASTELLANOS SANTAMARÍA, uno de los cerebros de la organización policial de postguerra, subrayando la superposición de la militancia política enemiga y la perversión carnal: "la revolución roja en marcha abismal, trágica, hacia el triunfo, estaba sembrada en las grandes densidades de población con la semilla de las milicias socialistas, veneros de ayuntamientos carnales nefandos, favorecidos, como no, por el monstruo masónico, o tropeles del alcohol y de la equivocación o la depravación ",55.

La psiquiatría "nacional" también aportó su grano de arena al argumentario legitimante de la eliminación del enemigo político como personaje espurio incompatible con el nuevo orden. De ello, denuncia GONZÁLEZ DURO, "se encargaron unos cuantos psiquiatras, henchidos de fervor patriótico, demostrando 'científicamente' que los 'marxistas' eran inferiores mentales,

\footnotetext{
51 TAMAMES, R., La República. La Era de Franco, Alianza Editorial-Alfaguara, Madrid, 1973, p. 142.

52 Preámbulo a la Ley de Reforma de la Enseñanza Media, de 20 de septiembre de 1938.

${ }^{53}$ SILVA BARRERA, E., y MACÍAS SANTIAGO, S., Las fosas de Franco, los republicanos que el dictador dejó en las cunetas, Temas de Hoy, Madrid, 2003, pp. 131-132.

54 UGARTE PÉREZ, F. J., “Las bases ideológicas de la represión”; en Una discriminación universal. La homosexualidad bajo el franquismo y la transición (edit. Ugarte Pérez, F. J.,), Egales Editorial, Barcelona-Madrid, 2008, p. 69.

${ }^{55}$ CASTELlanOS SANTAMARÍA, P., Policía integral o policía nacional sindicalista, Imprenta Católica F.G. Vicente, Valladolid, 1939, p. 76
} 
morales y espirituales, psicópatas antisociales que propendian a la subversión del 'orden natural' de las cosas" 56 .

La representación de la homosexualidad como degradación política no es exclusiva de la postguerra. Todavía en los albores de la "transición", la alucinación de MAURICIO KARL (seudónimo de Mauricio Carlavilla), sintetizada en su Sodomitas ${ }^{57}$, que conoció sucesivas reediciones desde 1956 a 1973, confirma la vigencia de la identificación sodomía-comunismopeligrosidad. Y no solo entre sus lectores: en las Cortes franquistas, el procurador VILLEGAS GIRÓN, mantuvo en 1970, en su defensa del art. 2, núm. 3 del proyecto de la Ley de Peligrosidad y Rehabilitación Social (en adelante, LPRS), que "afortunadamente somos una raza en que los hombres son hombres y las mujeres, mujeres. Y lo que no queremos es que existan estos espécimen (sic) hibridos "58.

\section{CRIMINALIZACIÓN DEL HOMOSEXUAL: LA PELIGROSIDAD}

\subsection{El constructo ideológico}

La construcción del sistema teórico de identificación y exclusión del homosexual como sujeto peligroso, nace en los estudios criminológicos del tránsito del siglo XIX al XX.

Es el momento de penetración del positivismo, ya consolidado como corriente filosófica y como metodología, en las ciencias penales. Las propuestas metafísicas, ancladas en un pretendido Derecho natural, son sustituidas por el estudio empírico del delincuente, como sujeto con determinadas características orgánicas, que el primer positivismo criminológico se encargó de estudiar con la fiebre clasificadora propia de la época. LOMBROSO, en Italia, y, unos años antes, CUBI I SOLER, en España, serían los corifeos de esta línea de trabajo, complementada por los autores -PRINS, VACCARO, FERRI-, que investigaron los factores sociales determinantes de la peligrosidad del sujeto ${ }^{59}$. La esperable consecuencia fue, tanto en las elaboraciones científicas como en los trabajos legiferantes, la identificación de ociosos, enajenados, huelguistas, anarquistas, vagabundos y prostituidos, como sujetos situados frente al sistema penal.

En España, las propuestas de la Scuola Positiva encontrarían un eco específico, pasado por el tamiz del krausismo de GINER DE LOS RIOS, y terminarían por cristalizar en el correccionalismo de DORADO MONTERO, el título de cuya obra más significativa $-E l$ Derecho protector de los criminales- constituye la enunciación de todo un programa tuitivo y

\footnotetext{
${ }^{56}$ GONZÁLEZ DURO, E., Los psiquiatras de Franco. Los rojos no estaban locos, Planeta, Madrid, 2008, p. 10.

${ }^{57}$ KARL, M., Sodomitas, NOS, Madrid, 1956.

${ }^{58}$ BOLETÍN OFICIAL DE LAS CORTES GENERALES, Diario de Sesiones. Comisión de Justicia, sesión de 22.06.1970, p. 17.

59 TERRADILLOS BASOCO, J. M., Regulación española de las medidas de seguridad y garantías individuales, Editorial de la Universidad Complutense de Madrid, Madrid, 1980, pp. 36-46.
} 
humanista, basado en la "justicia de bata blanca"60. Pero buena parte del argumentario excluyente del peligroso, elaborado por la doctrina militante en el positivismo criminológico, terminaría por ser apropiado por las formas totalitarias de organización del poder punitivo. Tal como muestra el ejemplo de FERRI -iniciado en el socialismo jurídico italiano ${ }^{61}$ para llegar a convertirse en estratega de la política criminal del fascismo ${ }^{62}$, la deriva totalitaria era el destino anunciado de una doctrina que había hecho renuncia expresa de las garantías penales y procesales, y que se movía en una dirección autoritaria, servil a los requerimientos de la defensa social $^{63}$

Los estudios criminológicos de BERNALDO DE QUIRÓS ya habían allanado el camino, al vincular, "de modo exageradamente explícito", ejercicio de la prostitución y homosexualidad, lo que permitía considerar a esta como socialmente peligrosa, en términos que alcanzarían su paroxismo a finales de la década de 1920, con la revista Sexualidad, publicada por NAVARRO FERNÁNDEZ y publicitada como instrumento de regeneración de la raza y la cultura españolas a través de la eliminación del "peligroso social" homosexual y de su propensión a cometer crímenes $^{64}$.

De hecho, la incorporación de la peligrosidad al CP de 1928 no respondió a los impulsos tuitivos del correccionalismo, sino a la influencia, políticamente más afín, de la corriente defensistautilitaria del positivismo criminológico.

\subsection{El reflejo normativo}

El CP de 1928 -calificado por la Exposición de Motivos (VI) de su sucesor de 1932 como conjunto de "normas facciosas" o "estatuto penal espurio"- en su parte general (Libro Primero), afronta la peligrosidad del homosexual implícitamente, al dar respuesta punitiva a circunstancias y situaciones a las que, en el contexto cultural e ideológico de la época, la homosexualidad era fácilmente reconducible. Así, agravan la responsabilidad del condenado su "vida depravada" (art. 67.1") y su "ociosidad o vagancia" (art. 67.5)); datos que pueden ser indicativos de peligrosidad criminal y legitimadores de la imposición de medidas de seguridad; entre ellas, las de internamiento y retención (art. 90).

Su art. 71 define el "peligro social criminal" como "el estado especial de predisposición de una persona, del cual resulte la probalidad (sic) de delinquir". Y cuando los tribunales hicieren,

\footnotetext{
60 TERRADILlOS BASOCO, J.M., "Vigencia del derecho penal del krausismo”, op. cit., pp. 37-40.

${ }^{61}$ NAVARRO DE PALENCIA, A., Socialismo y Derecho criminal, Reus, Madrid, 1919, p. 132.

62 TERRADILlOS BASOCO, J. M., Regulación española de las medidas de seguridad y garantías individuales, op. cit., pp. 43-45.

${ }^{63}$ MODONA, G. N., "Tecnicismo e scelte politiche nella riforma del codice penale", en Democrazia e Diritto, 4, 1977, p. 672.

${ }^{64}$ VÁZQUEZ GARCÍA, F.J., y CLEMINSON, R., Los invisibles. Una historia de la homosexualidad masculina en España, 1850-1939, op. cit., pp. 240 y 120-121.
} 
en sus sentencias condenatorias, "declaración de peligro social criminal", podrán imponer al condenado las medidas de seguridad procedentes.

Frente a los comportamientos homosexuales, el Código primorriverista, que "con torpeza anacrónica... no responde a concepción médica alguna, ya que sus redactores, sin guía ni norte, han caminado ciegos por una ruta desconocida" 65 , incorpora una respuesta alejada del debate científico de la época. Bajo la rúbrica de "delitos de escándalo público", castiga, en su art. 616, al que "habitualmente o con escándalo, cometiere actos contrarios al pudor con personas del mismo sexo". A observar que la fórmula tipificadora, alternativa comporta que las prácticas homosexuales habituales sean típicas siempre, aunque, en contradicción con la rúbrica, no den lugar a escándalo, definido en los términos del art. 617. También se castiga con pena agravada al responsable, con víctimas o partenaires del mismo sexo, de delitos de abusos deshonestos sobre adultos (art. 601) o sobre menores (art. 775).

El republicano CP de 1932 tipificaba, como delitos contra la honestidad diversas conductas abuso deshonesto "de persona de uno u otro sexo" (art. 432), ofensa al pudor o las buenas costumbres con hechos de grave escándalo (art. 433), favorecimiento de la corrupción de menores (art. 440)-, en las que los comportamientos homosexuales tienen fácil acomodo.

Cierto es que la represión va dirigida tanto a comportamientos homo- como heterosexuales, ya que unos y otros pueden resultar idóneos para afectar al bien jurídico proclamado por la rúbrica del Título X -la honestidad-, pero cierto es también que la proliferación de elementos típicos valorativos (abuso, deshonestidad, buenas costumbres, grave escándalo, vicio, etc.) facilitaría, en la época, juicios de desvalor más intenso cuando los hechos a examen incorporasen elementos homosexuales.

La LVM respondía a un paradigma diferente al del Código, al prever la imposición de medidas de seguridad a los sujetos declarados en estado peligroso, entre los que no se encontraban los homosexuales. Lo que condicionó que su persecución hubiera de realizarse acudiendo a otras etiquetas (conductas escandalosas, inmorales, etc.) menos específicas.

La Circular de la Fiscalía General de la República, de 12 de marzo de 1934, respalda este proceder interpretativo: la homosexualidad se integra en otras tipologías próximas (prostitución, rufianismo, etc.) consideradas, per se, peligrosas, con independencia de que los comportamientos enjuiciados sean o no constitutivos de delito y de que permitan vaticinar la comisión de delitos futuros o la simple marginalidad del sujeto. La peligrosidad predelictual y meramente social es el elemento sobre el que pivota todo el sistema, y así, en opinión de la Fiscalía, "rufianes y proxenetas, traficantes con la ajena honestidad para satisfacer la lujuria de otros, constituyen el inmundo pináculo de la suprema ignominia humana, el parasitismo de la prostitución y de la liviandad. Explotadores de seres infelices... sus indignas actividades, principal factor de la prostitución que promueven espiando, sitiando y captando a la ingenuidad, la ligereza y la necesidad, son siempre socialmente peligrosas, ya tengan o no

65 JIMÉNEZ DE ASÚA, L., “Epílogo”, cit., pp. 245-246. 
tipicidad delictiva y ya se ejerciten respecto de mujeres o de hombres, de mayores o de menores de edad, descubierta o clandestinamente".

En cualquier caso, si la LVM no exigía explícitamente la consideración de la homosexualidad como supuesto de estado peligroso, habilitante de la imposición de medidas de seguridad, sino que la admitía implícitamente, el Reglamento de 3 de mayo de 1935 amplió extraordinariamente -en contradicción flagrante con las exigencias del principio de legalidadel ámbito de aplicación, al entender incursos en el catálogo de sujetos peligrosos a quienes "por su forma de vida habitual, dedicada a actividades inmorales, demuestren un estado de peligrosidad por analogía con lo dispuesto en la Ley" (art. 1.G).

A su vez, el Código de Justicia Militar, de 1945 (art. 352) mantuvo el abuso deshonesto homosexual como delito autónomo "contra el honor militar".

Pero había de ser la Ley de 15 de julio de 1954 la que introdujera en la LVM la etiqueta explícita: podrán ser declarados en estado peligroso los homosexuales, rufianes y proxenetas, agrupados todos ellos en el nuevo art. $2^{\circ}$, núm. $2^{\circ}$, por más que, criminológicamente, se trate de tipologías bien diferenciadas.

La nueva legalidad hace tabula rasa de la posible diferenciación, propuesta incluso por CUELLO CALÓN -inspirador de leyes penales de las dictaduras primoriverista y franquista, y admirador de MEZGER por su condición de adepto al nacionalsocialismo ${ }^{66}$ - entre los casos en que "la conducta sexual anormal proviene de factores biológicos, de anomalías y defectos glandulares congénitos", necesitados de "curación y ajuste de su personalidad" y los de "prostituidos, hondamente depravados, muchos de ellos habituales de los bajos fondos criminales", acreedores, en cuanto peligrosos, de "eficaces medidas de protección social” 67. En la LVM, desde 1954 son peligrosos, sin distingos, todos los homosexuales.

Hacía poco tiempo que el primer franquismo, superadas las huelgas de enero de 1951 en Cataluña, había dejado atrás la etapa de la economía autárquica y del racionamiento, e iniciado, a impulsos de su integración en la política de bloques en que cristalizó la "guerra fría", un lento pero irreversible proceso de liberalización económica. El cambio, sin embargo, no se tradujo en un mayor respeto a la diversidad: a pesar de la innegable, aunque limitada, liberalización intelectual $^{68,}$ el retroceso en la lucha contra la heterodoxia en materia sexual, representado por la reforma de la LVM, se asienta en un contexto mundial conservador, marcado políticamente por la "guerra fría", potenciada además por el estallido de la guerra de Corea (1950), que

\footnotetext{
66 TERRADILlOS BASOCO, J.M., “Construcción y enseñanza del Derecho penal del Muevo estado. Los orígenes del Código Penal de 1944”, op. cit., p. 216.

67 CUELlO CALÓN, E., "Referencias históricas y de derecho comparado sobre la represión de la homosexualidad”, en Anuario de Derecho Penal y Ciencias Penales, VII.3, 1954, p. 501. pp. 498-501

${ }^{68}$ DÍAZ GARCÍA, E., Pensamiento español en la era de Franco (1939-1975), Tecnos, Madrid, 1983, p. 63.
} 
incrementó la importancia militar de España como eslabón seguro y socio fiable en el cerco occidental a la amenaza comunista ${ }^{69}$.

La solidez del bloque ideológico regresivo comenzó, sin embargo, a resentirse a partir de los sesenta, cuando la liberalización económica y la apertura de fronteras favorecieron el intercambio de mercancías y personas, pero también el de información.

La emigración por razones laborales empujó en el mismo sentido, pero, por razones no solo cuantitativas, con menor fuerza que el turismo.

La afluencia masiva de turistas, y, por tanto, de costumbres sexuales desviadas respecto a la ortodoxia carpetovetónica, comportaba el riesgo de contagio de una degradante promiscuidad foránea que el régimen, aunque deslumbrado por el aporte de divisas, no estaba dispuesto inicialmente a aceptar de buen grado, y en 1958, desde la Dirección General de Seguridad se impulsó la "veda hispánica del uso del bikini". Pero la reivindicación nostálgica de los viejos valores hubo de ceder ante el impulso de los ingresos aportados por unos visitantes, mayoritariamente jóvenes, que introdujeron sus modelos de liberación sexual, inconformismo, ruptura generacional, indiferencia religiosa, y emancipación femenina ${ }^{70}$. Las nuevas formas de entender las relaciones sexuales conectaban, además, con las reivindicaciones de inspiración democrática, incipientes aunque duramente reprimidas, ya instaladas en el interior, sobre todo en los campus universitarios. La revisión de las escalas de valores integristas operada en la década de los sesenta respondió más que a las directrices emanadas del Boletín Oficial del Estado, a la penetración, por ósmosis, de los valores foráneos.

Años más tarde, en 1970, la LPRS vendría a constituir, como exhibe su Preámbulo, una puesta al día de la LVM, que, si bien había supuesto un avance constatable, necesitaba adecuarse a "los cambios acaecidos en las estructuras sociales, la mutación de costumbres que impone el avance tecnológico, su repercusión sobre los valores morales, las modificaciones operadas en las ideas normativas del buen comportamiento social y la aparición de algunos estados de peligrosidad característicos de los países desarrollados que no pudo contemplar el ordenamiento de mil novecientos treinta y tres".

Es importante reparar en cómo la LPRS acepta que una de las razones que avalan su reforma para alcanzar el objetivo de determinar mejor las "categorías subjetivas de peligro", radica en "las modificaciones operadas en las ideas normativas del buen comportamiento social”. Dicho de otro modo: la peligrosidad personal no deriva tanto de las características del individuo, sino de criterios que le son ajenos, y que dependen de modelos normativos elaborados en las instancias con poder para definir qué comportamientos son socialmente adecuados y cuáles no. Si GINER había mantenido que cada época de la Historia tiene su Derecho natural propio, DORADO llega a afirmar que "son delincuentes aquellos individuos que hayan sido declarados

\footnotetext{
${ }^{69}$ TAMAMES, R., La República. La Era de Franco, op. cit., pp. 460.461.

70 SÁNCHEZ SÁNCHEZ, E. M., "El auge del turismo europeo en la España de los años sesenta", en Arbor, CLXX. 669, 2001, pp. 208 y 220.
} 
tales oficialmente, por medio de sentencia judicial; todos los demás son honrados...Son delitos aquellos actos que el más poderoso prohíbe ejecutar y cuya realización conmina con penas. Es decir, que el concepto de delito es de esta suerte un concepto impuesto"71. Y a esta realidad, trasladada del ámbito del delito al de la peligrosidad, se adecúa la LPRS.

La LPRS modificó, y de manera relevante, la configuración del supuesto de estado peligroso, que dejó de ser una característica personal -la homosexualidad- para radicarse en unos comportamientos concretos: su art. 2 dispone que "Son supuestos del estado peligroso los siguientes: Tercero. Los que realicen actos de homosexualidad".

La Ley 43/1974, de 28 de noviembre, modificó determinados artículos de la LPRS, sin incidencia directa relevante en el tema ahora objeto de estudio, pero la Ley 77/1978, de 26 de diciembre, coetánea con la entrada en vigor de la entonces nueva Constitución democrática, procedió a la derogación del apartado tercero del art. 2 LPRS, con lo que las prácticas homosexuales dejaron de constituir el presupuesto legitimante de la imposición de medidas de seguridad.

\subsection{A. Peligrosidad de la homosexualidad}

La Ley de 15 de julio de 1954, al modificar el art. $2^{\circ}$ de la LVM, consagró la represión expresa y autónoma de la homosexualidad: "Podrán ser declarados en estado peligroso... Segundo: Los homoxesuales (sic), rufianes y proxenetas". La grafía del BOE refleja el distanciamiento cultural entre legislador y realidad legislada.

Aunque los homosexuales habían venido siendo consuetudinariamente perseguidos en aplicación de los tipos de escándalo público o de abusos deshonestos, el legislador reivindica la necesidad de su represión personal específica: "la producción de hechos que ofenden la sana moral de nuestro país por el agravio que causan al tradicional acervo de buenas costumbres, fielmente mantenido en la sociedad española, justifican la adopción de medidas para evitar su difusión" (Preámbulo).

La decisión político-criminal de positivizar la represión autónoma del homosexual no carece de relevancia, por cuanto el control, ya formal (debilitado por el silencio legal) ya informal, genera en el colectivo controlado mecanismos de resistencia más o menos eficaces, que quedan, sin embargo, neutralizados cuando el control pasa a ser inequívocamente institucional y queda legitimado como manifestación del indiscutido ius puniendi.

La respuesta penal de la reforma de 1954 a la homosexualidad es ejemplo de peligrosidad meramente social. El art. 2 eclara peligrosos a los homosexuales junto a rufianes y proxenetas, pero mientras estos quedan definidos por su comportamiento con proyección externa, la condición homosexual es producto de una descalificación personal. Rufián y proxeneta, en efecto, trafican con otros y obtienen beneficios; se lucran ilícitamente de la prostitución ajena. Y, con ello, no solo cometen delitos; además pueden suministrar indicios de que los seguirán

\footnotetext{
${ }^{71}$ DORADO MONTERO, P., Bases para un nuevo Derecho Penal, Gallach, Barcelona 1923, p. 21.
} 
cometiendo (peligrosidad criminal). Pero el homosexual se limita a compartir su sexualidad con individuos del mismo sexo, a los que no agrede, coacciona o explota. La única peligrosidad que puede generar su condición es la probabilidad de seguir dirigiendo su práctica sexual a los mismos objetivos. Solo amenaza con "la producción de hechos que ofenden la sana moral de nuestro país por el agravio que causan al tradicional acervo de buenas costumbres, fielmente mantenido en la sociedad española”. Y esto le resulta al legislador intolerable.

Se persigue, pues, a "sujetos caídos al más bajo nivel moral" para que, corregidos y reformados, salgan de la degeneración. No importa -en una ley penal (i)- la proximidad o alejamiento del homosexual respecto al delito: se trata, explica el Preámbulo de la ley, de "proteger la paz social y la tranquilidad pública contra las actividades no constitutivas de delito o cuya delincuencia consta, pero no puede ser inmediatamente probada, de sujetos que, por su habilidad, escapan a través de las mallas de la Ley o eluden su aplicación, por cuya causa constituyen un serio peligro para una ordenada vida de la colectividad".

La homosexualidad queda así configurada como el paradigma de supuesto de peligrosidad personal -no se define por lo que se hace, sino por lo que se es-, predelictual -no requiere prueba, y ni siquiera comisión, de un delito previo- y social, por cuanto la persistencia en la condición homosexual, manifestada al exterior o no, constituye una amenaza para el "tradicional acervo de buenas costumbres".

El basamento teórico se aproxima más que a los aportes del positivismo criminológico, a las propuestas político-criminales, gestadas en MEZGER y en la Escuela de Kiel, de responsabilidad por el carácter o por la conducción de vida: tesis negadoras, en definitiva, del derecho a vivir de forma equivocada, lo que legitimaría ser tratado como enfermo o como enemigo $^{72}$.

Una vez más, la norma penal va a desplegar objetivamente la función no de tutela de bienes jurídicos a través de la neutralización preventiva del peligroso, sino la de cohesión ideológica del colectivo propio, a través de la estigmatización de los “otros", labor especialmente rentable, por fácil, cuando la cuestión sexual suplanta, como objeto de reflexión político-criminal, a la cuestión penal.

\subsection{B. Peligrosidad por actos homosexuales}

Cuando la LPRS (art. $2^{\circ} \mathrm{B}$, tercero) declara "en estado peligroso" a "los que realicen actos de homosexualidad", introduce un modelo distinto al de su predecesora, la LVM: configura un tipo de hecho, frente al anterior tipo de autor. Se trata, dice el Preámbulo (IV) -reincidiendo en el dislate gráfico en que incurrió el legislador de 1954-, de poner el acento en los "actos de homoxesualidad" para eliminar toda posible ambigüedad de la figura, que ha quedado objetivada por la referencia a los hechos.

\footnotetext{
72 FERRAJOLI, L., Derecho y Razón. Historia del garantismo penal, Trotta, Madrid, 1995, p. 496.
} 
Mientras en otros supuestos la declaración de estado peligroso requiere la valoración de una forma de vida o de una determinada personalidad (toxicómanos, menores moralmente pervertidos), o la habitualidad de comportamientos (prostitución, mendicidad, ebriedad), en el caso de la homosexualidad, la validez de la etiqueta de peligroso se deduce en la LPRS mecánicamente de los actos homosexuales. Lo que no es detalle trivial, por cuanto las medidas de seguridad -al menos hasta la bizarra argumentación en sentido contrario de la LO 5/2010, Preámbulo $\mathrm{IV}^{73}$ - deben responder a las características personales de un sujeto, no a sus comportamientos concretos, que, como mucho, podrán tener valor indiciario, pero no constitutivo, de peligrosidad ${ }^{74}$. Como ya en su momento se advirtió en doctrina, la LPRS optó, en este punto, por la imposición de medidas de seguridad por lo que se hace, no por lo que se es, en contra de lo exigido por la coherencia científica ${ }^{75}$.

Cierto es que, en las resoluciones de las Salas de Apelación de Peligrosidad, la declaración de peligrosidad del homosexual se asentaba no solo en el pilar de los actos de "inversión sexual" -entendiendo por tales los de "ayuntamiento carnal" entre personas del mismo sexo, y "en general, los tocamientos lascivos de toda índole efectuados por invertidos sexuales entre sí" , sino también en el de las características personales, esto es, en la indudable peligrosidad social derivada de la "perversidad o desviación del instinto sexual". Pero la exigencia de este segundo elemento es pura tautología: se deduce mecánicamente de la reiteración de comportamientos homosexuales a través de los cuáles "se incide en el buen orden social" "76. La argumentación es circular y vacua: los hechos son, a la vez, indiciarios y constitutivos de peligrosidad.

La entrada en vigor de la Constitución, y sobre todo, el espíritu garantista que, a su tenor, ha de impregnar todo el sistema penal, obligó al Tribunal Constitucional a ciertos pronunciamientos -fundamentalmente las sentencias 23/1986 y 21/198777 - que, en la práctica, hicieron de la LPRS una norma inaplicable. Porque al declarar la vigencia del principio de postdelictualidad, excluyeron, del catálogo de supuestos de estado peligroso, los predelictuales, entre ellos la realización de actos homosexuales; y, al hacer lo propio con el principio non bis in idem, limitaron el campo de eventuales sujetos peligrosos a los inimputables: los imputables, peligrosos o no, eran castigados con pena, y yuxtaponer otra consecuencia de aflictividad similar con el mismo fundamento supondría incurrir en la proscrita doble sanción ${ }^{78}$.

\footnotetext{
${ }^{73}$ ACALE SÁNCHEZ, M., "Libertad vigilada”, en Comentarios a la reforma penal de 2010 (dir. Álvarez García, F.J., y González Cussac, J.L.), Tirant lo Blanch, Valencia, 2010, pp. 150-151.

${ }^{74}$ JORGE BARREIRO, A., Las medidas de seguridad en el Derecho español, Civitas, Madrid, 1976, p. 203.

${ }^{75}$ CONDE-PUMPIDO FERREIRO, C., “Aspectos substantivos de la Ley de Peligrosidad y Rehabilitación Social de 4 de agosto de 1970", en AA.VV., Temas Penales, Universidad de Santiago de Compostela, Santiago de Compostela, 1973, p. 227.

76 JORGE BARREIRO, A., Las medidas de seguridad en el Derecho español, op. cit., pp. 204-205.

77 Sentencias del Tribunal Constitucional 23/1986, de 14 de febrero, ECLI:ES:TC:1986:23; y 21/1987, de 19 de febrero, ECLI:ES:TC:1987:21.

78 TERRADILLOS BASOCO, J.M. “Capítulo XI. Las medidas de seguridad”, en MAPELLI CAFFARENA, B., y TERRADILLOS BASOCO, J.M., Las consecuencias jurídicas del delito, $3^{\text {a }}$ ed., Civitas, Madrid, 1996, pp. 202-
} 203. 


\section{DISCIPLINA Y CONTROL: LAS MEDIDAS DE SEGURIDAD}

\subsection{Medidas}

Las medidas reservadas por el art. 6, 2 de la LVM, a partir de la Ley de 15 de julio de 1954, para los "homoxesuales" (sic), junto a rufianes, proxenetas, mendigos profesionales, explotadores de la mendicidad ajena o de menores, enfermos mentales o lisiados, son " $a$ ) Internado en un establecimiento de trabajo o Colonia Agrícola. Los homoxesuales (sic) sometidos a. esta medida de seguridad deberán ser internados en, Instituciones especiales, y, en todo caso, con absoluta separación de los demás. b) Prohibición de residir en determinado lugar o territorio y obligación de declarar su domicilio. c) Sumisión a la vigilancia de los Delegados".

La finalidad de las medidas es tanto preventivo-general, "garantía colectiva", como especial, "aspiración de corregir a sujetos caídos al más bajo nivel moral. No trata esta Ley de castigar, sino de proteger y reformar" (Preámbulo).

Las colonias agrícolas habían quedado reguladas en el Reglamento para la aplicación de la LVM, de 3 de mayo de 1935, aprobado bajo el gobierno de Lerroux una vez yugulada la "Revolución de Asturias" por los regulares y legionarios dirigidos por el general Franco. Su art. 4 dispone que las colonias "se establecerán en regiones en que haya facilidades de explotar grandes extensiones de terreno, aplicándose los adelantos modernos de maquinaria, y pudiendo el Estado poner al frente de los trabajos, para el mejor éxito de los mismos, Ingenieros, Peritos o prácticos, o procurar su asesoramiento y dirección. Se procurará destinar a estos Establecimientos a los peligrosos de origen rural, empleándoles en operaciones qué los hagan aptos para que, una vez regenerados, puedan ser obreros útiles en las faenas agrícolas".

El art. 25 del Reglamento es más concreto en cuanto a contenidos del tratamiento, por más que sea difícil establecer la relación de las prácticas que se promocionan con la superación de la homosexualidad de los peligrosos internados: "En las Colonias agrícolas se procurará perfeccionar a los que a ellas sean destinados en las prácticas que posean, adiestrarles en el manejo de los útiles y maquinaria agrícola modernas y capacitarles con conocimientos complementarios tales como análisis, mejoras y enmiendas de tierras, seleccionado de semillas, abonos, conservación y aprovechamiento de productos, ganadería, avicultura, cunicultura, apicultura e industrias derivadas, siempre que ello sea posible”.

Al regular los procedimientos de revisión de las medidas de seguridad, el Reglamento preveía la posibilidad de decretar un nuevo internamiento "si el asegurado reincidiese en sus malas costumbres o sigue demostrando inclinación al vicio y a la frecuentación de lugares reprobables o al trato con gente de su antigua condición" o en atención a su "resistencia para el trabajo y su tendencia a la vagancia o a practicar actos reprobables, al alcoholismo, perversiones sexuales, prostitución, protección de actos inmorales o trato con maleantes de todas clases". No es descabellado entender que, si el sistema de ejecución obliga al interno homosexual peligroso a compartir establecimiento solo con otros homosexuales igualmente 
peligrosos, las posibilidades de que rehúya la frecuentación o el trato con "gente de su antigua condición" o con otros "maleantes", son más que escasas.

En cualquier caso, estos programas reinsertadores específicos se integran en marcos de tratamiento más complejos y ambiciosos, en los que es primordial la formación religiosa: " $L a$ creación en el sujeto peligroso de una conciencia religiosa cuando carece de ella o es insuficiente -advierte OLESA-, constituye una condición indispensable para restaurar en si mismo el orden moral, necesario antecedente para la eliminación de su personalidad anti o asocial... Religión, trabajo, asistencia médica y psiquiátrica e instrucción cultural son los medios de ejecución que al combatir las causas del estado peligroso posibilitan la futura integración del individuo peligroso en la Sociedad"79.

De acuerdo con lo previsto en el Reglamento de 1935, una Orden del Ministerio de Justicia de 15 de enero de 1954 crea, a la vista de "la necesidad de un nuevo Establecimiento de Defensa social" una colonia agrícola para el tratamiento de Vagos y Maleantes en Tefía, en la isla de Fuerteventura.

La colonia nace en los terrenos de un aeródromo en desuso, cedidos por el Ministerio del Aire, en los que seis funcionarios del Cuerpo de Prisiones y doce presos iniciarían inmediatamente los trabajos de acondicionamiento de las viejas instalaciones. El pedregoso desierto majorero iba a ser, a partir de entonces, el escenario cruel de una de las páginas más negras de la historia penitenciaria española ${ }^{80}$.

Antes, entre 1940 y 1947, el campo de concentración de Nanclares de Oca -un conjunto de barracones construido por un destacamento de prisioneros de guerra- había dado cobijo a cientos de homosexuales, condenados en aplicación de la LVM, antes de que el Derecho contemplara expresamente la homosexualidad como supuesto de estado peligroso. Los encarcelados fueron sometidos a trabajos forzoso, especialmente en la construcción de infraestructuras viarias.

Por su parte, el Reglamento de Prisiones, modificado por el Decreto 162/1968, de 25 de enero, disponía que "los establecimientos de cumplimiento o de corrección destinados al cumplimiento de sentencias que impliquen privación de libertad comprenderán: al Centros hospitalarios y asistenciales, ... ... Centros de psicópatas, de pervertidos sexuales, de deficientes mentales y, en general, todos aquellos en que se preste una asistencia de carácter no especificamente penitenciaria" (art. 5). Precisando, en línea con las propuestas criminológicas institucionales del momento ${ }^{81}$, que "por exigencias de un tratamiento hospitalario o asistencial serán destinados... ...: g) a establecimientos de pervertidos

\footnotetext{
${ }^{79}$ OLESA MUÑIDO, F.F., Las medidas de seguridad, Bosch, Barcelona, 1951, p. 163.

${ }^{80}$ SOSA MACHÍN, M.A., Viaje al centro de la infamia, Anroart, Las Palmas de Gran Canaria, 2006, p. 81.

81 LAGUÍA ARRAZOLA, A., "Homosexualidad y delincuencia mentalmente anormal", en XI Curso Internacional de la Sociedad Internacional de Criminología. Los delincuentes mentalmente anormales. Conferencias y Comunicaciones, (edit. Castro, B.F., y Cobo del Rosal, M.), Universidad de Madrid-Facultad de Derecho, Madrid, 1961-1962, p. 393.
} 
sexuales, los conocidos como homosexuales genuinos o congénitos y los homosexuales de hábito" (art. 23).

Una vez aprobada la LPRS y su Reglamento de aplicación (13 de mayo de 1971) se dispuso el cumplimiento de las medidas de seguridad para homosexuales en las cárceles de Huelva y Badajoz, destinadas, respectivamente, a invertidos "pasivos" y "activos" 82.

La previsión específica de aislamiento de los grupos de homosexuales, en contra del régimen previsto para el resto de sujetos peligrosos, es reflejo de la ideología subyacente: ya no se trata de evitar que puedan desplegar su peligrosidad criminal -que habría quedado neutralizada por el internamiento- en la sociedad, sino también en los ámbitos carcelarios, porque el homosexual es peligroso, como es inmoral o enfermo- per se, en cualquier ambiente y en cualquier condición.

De ahí que no se le sitúe en marcos plurisexuales, aptos en principio para su integración en la sexualidad "sana", en la convicción de que terminará corrompiéndolos, Antes bien, se le obliga al contacto, excluyente de otras alternativas, con internos igualmente homosexuales, ámbito que no parece el más idóneo para su recuperación. Lo que no encierra contradicción, pues el tratamiento -aislamiento y disciplina laboral, por tiempo indeterminado aunque sin exceder de tres años- no va dirigido a que el homosexual pueda, una vez superada su peligrosidad, llevar una vida en libertad alejada del delito, sino a que deje de actuar como tal.

La infradotación de medios estructurales -garantizada por la ausencia de previsiones presupuestarias en el momento de aprobación de la $\mathrm{LVM}^{83}$ - es una constante durante su período de vigencia, a lo largo del cual, de facto, los establecimientos especializados son suplidos por cárceles comunes ${ }^{84}$. $\mathrm{Y}$, cuando se pretende la ejecución de las medidas de seguridad en los especializados, como Tefía, los tratamientos quedan reducidos a los efectos aflictivos de la pena privativa de libertad ${ }^{85}$, incrementados con la obligación de trabajar hasta la extenuación en condiciones de alimentación y salubridad deplorables. De esta suerte, la situación de los presos homosexuales no difería en exceso de los presos comunes, ${ }^{86}$ tanto en los establecimientos $a d$ hoc como en las prisiones de cumplimiento de penas, en las que aquellos sufrieron, además,

\footnotetext{
${ }^{82}$ ALTMANN, W., "Vicio repugnante en lo social, aberración en lo sexual, perversión en lo psicológico y defecto en lo endocrino. Un ensayo bibliográfico sobre la homosexualidad y los homosexuales bajo la dictadura franquista", en Iberoamericana, 22, 2006, pp. 196-197.

${ }^{83}$ FAIRÉN GUILLÉN, V., "Prevención y represión desde el punto de vista procesal”, en Anuario de Derecho penal y Ciencias penales, 1, 1971, p. 48.

${ }^{84}$ SABATER TOMÁS, A., Gamberros, homosexuales, vagos y maleantes (Estudio jurídico-sociológico), Editorial Hispano Europea, Barcelona, 1962, pp. 37-38.

${ }^{85}$ FISCALÍA DEL TRIBUNAL SUPREMO, Memoria 1967, p. 59.

${ }^{86}$ ARNALTE BARRERA, A., "Galería de invertidos, vida cotidiana de los homosexuales en las cárceles de Franco”, en Orientaciones. Revista de las homosexualidades, 7, 2004, p. 104.
} 
formas específicas de trato vejatorio o degradante, ya por parte de compañeros celosos de la moralidad o aprovechados chantajistas, ya por parte de ímprobos carceleros ${ }^{87}$.

\subsection{Procedimientos}

El poder de etiquetación en razón de criterios tan evanescentes como son todos los aplicables en el ámbito de la peligrosidad social, y más si se trata, en concreto, de determinar qué comportamientos homosexuales pueden tener relevancia penal, de decidir cuándo es sólido un pronóstico de peligrosidad personal derivado de la condición de homosexual del sujeto, y, finalmente, de imponer aquellas medidas de seguridad adecuadas para lograr su resocialización, requiere disponer de un procedimiento idóneo. Que, en la mentalidad de los sucesivos cuerpos legisladores, era tanto como un procedimiento que acogiese generosamente valoraciones extrapenales y que les diera cauce flexible, aligerando, en nombre de la eficiencia preventiva, los estándares requeridos para diagnosticar y pronosticar con rigor científico y con garantías jurídicas.

Al respecto, el Preámbulo de la LPRS, constata que, "en el plano procesal, la Ley [LVM] arbitró un procedimiento ajustado a un criterio de simplicidad y urgencia. Las medidas de seguridad, en resumen, tendían a apartar temporalmente de la vida social al peligroso, pero con el fin de darle educación y lograr su readaptación a la sociedad, confiriendo intervención a los órganos jurisdiccionales en la comprobación de los resultados del tratamiento impuesto”.

La declaración de peligrosidad y la aplicación de medidas de seguridad es, pues, un acto jurisdiccional, dirigido, en opinión de OLESA, a la averiguación de los hechos justificantes de la condición de homosexual del sujeto enjuiciado. Ya que "su existencia intima sin ninguna proyección externa sería irrelevante ante la Ley por la imposibilidad absoluta de constatación y conocimiento" $" 88$.

En garantía del principio de jurisdiccionalidad, el art. 10 de la LVM atribuye la competencia para declarar el estado peligroso y para aplicar las correspondientes medidas de seguridad, a "los actuales Jueces de Instrucción o los que especialmente sean designados para estas funciones".

Solo la limitación de recursos con los que había de comenzar a caminar la nueva ley, puede explicar la atribución a unos mismos jueces de procesos preventivos y represivos. Se trataba de aplicar a la peligrosidad sin delito, que la LVM "admitió por primera vez en el mundo y ello proclama FAIRÉN- debe enorgullecernos como españoles", un procedimiento construido para llegar a imponer penas por el delito cometido: "Es sencillamente absurdo"89.

\footnotetext{
${ }^{87}$ OLMEDA NICOLÁS, F., El látigo y la pluma, op. cit., pp. 181-182.

${ }^{88}$ OLESA MUÑIDO, F.F., Las medidas de seguridad, op. cit., 152.

${ }^{89}$ FAIRÉN GUILLÉN, V., "Prevención y represión desde el punto de vista procesal”, op.cit., 1, 1971, pp. 9-10.
} 
A pesar de que el art. 10 de la ley sugería la apertura de un proceso de selección de jueces basado en el principio de especialización, lo cierto es que solo en Madrid y Barcelona se establecieron jueces especializados, manteniéndose en los demás casos una acumulación no discriminante, en cuya virtud los juzgados pasaron a ser tricéfalos: "de primera instancia en lo civil; de instrucción, en lo criminal -represivo- y de primera instancia para Vagos y Maleantes" $"$.

La Ley 43/1974 modificó el art. 8 de la LPRS -heredero, a su vez, del comentado art. 10 de la LVM- para conferir "la facultad de declarar el estado peligroso e imponer las respectivas medidas de seguridad... exclusivamente a la jurisdicción ordinaria a través de los Juzgados de Peligrosidad y Rehabilitación Social, de cometido único, con la sede y el ámbito territorial que se establezcan".

El procedimiento garantizaba la presencia del presunto peligroso en todas las etapas de la primera instancia, con asistencia letrada a partir de la fase de propuesta de pruebas, que solo podrían tener por objeto o "la demostración de que el denunciado ha vivido, durante los cinco años anteriores, de un trabajo o medio de subsistencia legítimo", o "la inexactitud de los hechos que consten en el expediente y la tacha de los testigos que la hayan aducido" (LVM, art. 13). Lo que, de hecho, viene a significar que la prueba de solvencia económica cierra prácticamente las puertas a la apreciación de peligrosidad, mientras que, en sentido contrario, la constatación de carencia de medios las abre. La observación es directamente aplicable al primero de los supuestos de peligrosidad, que, además, dio nombre a la ley: los vagos habituales, cuya caracterización como peligrosos dependía, en primer lugar, de su condición de indigentes; en otro caso, su desafección al trabajo no era síntoma de peligrosidad, sino de capacidad económica ${ }^{91}$. Pero, también en el campo de la homosexualidad, el primer dato que reflejan los expedientes incoados a los internados en la Colonia Agrícola de Tefía es el relativo a su condición de sujetos indigentes o de ingresos irregulares y escasos.

Una vez practicadas las pruebas, y producidas las alegaciones procedentes por parte del Ministerio Fiscal y el presunto peligroso -ya que nadie más, ni siquiera el denunciante, podían ser parte-, se dictaría resolución en forma de sentencia (art. 14).

En caso de recurso -solo procedería el de apelación "ante la Audiencia provincial correspondiente o ante las Salas que al efecto se designen" (art. 15)-, las diligencias acordadas se practicaban “con o sin intervención de las partes, según el Tribunal determine”.

En términos generales, la doctrina procesalista del momento calificó al procedimiento de aplicación de la LVM -no modificado en sus principios por la LPRS-, de inquisitivo, con todas las características que autorizan tal calificación: posibilidad de apertura a iniciativa de la Policía

\footnotetext{
${ }^{90}$ FAIRÉN GUILLÉN, V., "Prevención y represión desde el punto de vista procesal”, op. cit., p. 18.

${ }^{91}$ TERRADILLOS BASOCO, J.M., "Un supuesto de estado peligroso: la vagancia habitual”, en Materiales, 10 , 1978 , p. 88.
} 
o de denuncia de particulares, secreto, unicidad de juez instructor y sentenciador, principio de escritura, doble instancia, y admisión de la "prisión provisional"92.

\subsection{Aplicación}

Con carácter general, puede afirmarse que el aparato penal represor inaugurado por la LVM no tuvo la aplicación ilimitada para la que, prescindiendo de formas y garantías, había sido diseñado.

El control policial de la calle -favorecido por el entendimiento de la delación como deber patriótico, practicado sobre todo por militantes falangistas privados ${ }^{93}$ - fue mucho más intenso que el jurisdiccional. Así, mientras las redadas y detenciones pudieron ser numerosas, con alrededor de cincuenta mil personas fichadas, los expedientes con resolución condenatoria solo se abrieron "en contadas ocasiones" 94 .

La situación económica del homosexual funcionó como poderoso filtro de selección, de suerte que las sentencias condenatorias quedaron reservadas, de hecho, para los indigentes ${ }^{95}$. Y no sin razón: "los bujarrones -se ha observado- constituyen el colectivo que crea el Estado franquista para reprimir a los malos homosexuales pobres, y este colectivo considerado delincuente constituye el principal foco del primer período de aplicación de la Ley de Peligrosidad... con ecos de prácticas anteriores de la Ley de Vagos y Maleantes, donde clase social y homosexualidad también venían conectadas" $" 96$.

En efecto, la mayoría de funcionarios, empleados o hijos de "familias bien" que, tras su detención en urinarios públicos, "bares de ambiente" o parajes urbanos recónditos pasaban por comisaría, salían en libertad sin más consecuencias que una amonestación, una detención de horas o días, una paliza o las consabidas vejaciones, aunque frecuentemente no fueron consecuencias alternativas, sino acumulativas ${ }^{97}$. Por su parte, el art. 352 del Código de Justicia Militar, de 1945, que castigaba el sexo entre varones, conoció idéntica lenidad discriminatoria cuando hubo de aplicarse a jefes y oficiales ${ }^{98}$.

De este modo, la LVM fue utilizada "con finalidades gubernativas (de orden público) y muy ajenas al propósito criminológico con el que se había dictado". De hecho, los objetivos

\footnotetext{
${ }^{92}$ FAIRÉN GUILLÉN, V., "Prevención y represión desde el punto de vista procesal”, op. cit., pp. 20-22.

${ }^{93}$ OLMEDA NICOLÁS, F., El látigo y la pluma, op. cit., p. 113.

${ }^{94}$ CHAMOULEAU, B., Tiran al maricón. Los fantasmas queer de la democracia (1970-1988), Akal, Madrid, 2017, p. 171.

${ }^{95}$ MORA GASPAR, V., Al margen de la naturaleza. La persecución de la homosexualidad durante el franquismo. Leyes, terapias y condenas, op. cit., p. 16.

${ }^{96}$ CHAMOULEAU, B., Tiran al maricón. Los fantasmas queer de la democracia (1970-1988), op. cit., p. 165.

${ }^{97}$ ARNALTE BARRERA, A., "Galería de invertidos, vida cotidiana de los homosexuales en las cárceles de Franco", op. cit., p. 104.

${ }^{98}$ OLMEDA NICOLÁS, F., El látigo y la pluma, op. cit., p. 130.
} 
criminológicos se revelaron prontamente inaccesibles "por falta de personal idóneo y de establecimientos adecuados para su puesta en práctica, lo cual llevó a que los tribunales de justicia -con gran sensibilidad- se mostraran reacios a aplicar la LVM"99.

Ya JIMÉNEZ DE ASÚA había advertido, en 1933, que "La cifra elevadísima dada por los periódicos sobre hipotéticos sujetos a quienes la ley alcanza, me hace pensar que las Autoridades y los Jueces creen que a todo el que encaje en las categorías del artículo $2{ }^{\circ}$ se le debe sentenciar como temible. Apresurémonos a decir que no. El articulo $2{ }^{\circ}$ comienza diciendo que "podrán ser declarados en estado peligroso"; pero no que fatalmente lo han de ser" 100 .

Según los cálculos de la Asociación de Ex-Presos Sociales, cerca de cuatro mil personas fueron privadas de libertad por ser homosexuales durante el franquismo, aunque la cifra es susceptible de correcciones, por cuanto solo a una parte de ellos se les aplicó la LVM $^{101}$ o, más tarde, la LPRS, mientras que otros, sobre todo antes de 1954, sufrieron sentencias condenatorias por la comisión de delitos de escándalo público o relacionados con la prostitución.

El tránsito de la LVM a la LPRS se tradujo en una mayor presión punitiva: si en 1969 el número de personas sometidas a medidas de seguridad era de ochocientas cuatro, en 1971 ascendió a mil ciento treinta. Con todo, y quizá por la reiteradamente denunciada -incluso por la Fiscalía del Tribunal Supremo- parquedad de medios, los Jueces de Peligrosidad tropezaron, al aplicar la Ley de 1970, con numerosas dificultades, a las que, seguramente, se añadiría "una elogiable prudencia" al enjuiciar ${ }^{102}$, limitando así el alcance de unos preceptos en los que, a espaldas de los principios de legalidad y taxatividad, cabía todo.

Lo que viene a corroborar una afirmación anterior, en el sentido de que las leyes represoras de la homosexualidad, más allá de la negación arbitraria de derechos fundamentales a través de sentencias condenatorias, desplegaron su eficacia en un plano paralelo y más difuso: el de la uniformización social en torno a valores queridos -por instrumentales- a los sectores hegemónicos, por medio de la estigmatización de chivos expiatorios cuya peligrosidad era nula para los bienes jurídicos fundamentales, pero muy alta para las formas autoritarias de poder, político o ideológico, cuya sola legitimación esgrimible radicaba en su capacidad para garantizar el pensamiento y la emoción únicos, a través de implacables cruzadas contra la insurgencia y la desviación.

El programa de integración social asentado en la unicidad ideológica convivió con -o quizá exigió- el implacable trato dispensado, tanto en Tefía como en Nanclares, Huelva, Huesca o

\footnotetext{
${ }^{99}$ JORGE BARREIRO, A., "Reflexiones sobre la regularización de las medidas de seguridad en el Nuevo Código Penal Español”, en Jueces para la Democracia, 25, 1996, p. 47.

100 JIMÉNEZ DE ASÚA, L, “Ley de Vagos y Maleantes. Un ensayo legislativo sobre peligrosidad sin delito", en Revista General de Legislación y Jurisprudencia, 163, 1933, p. 632.

${ }^{101}$ LAGUÍA ARRAZOLA, A., "Homosexualidad y delincuencia mentalmente anormal”, op. cit., p. 393.

102 JORGE BARREIRO, A., Las medidas de seguridad en el Derecho español, op. cit., p. 303.
} 
Badajoz, a los internos homosexuales. El trabajo forzoso, la pobreza de instalaciones y medios de subsistencia, el trato vejatorio, cuando no abiertamente delictivo de compañeros y carceleros, componían un marco inhumano que integraba también las prácticas de tortura ad hoc.

No pueden resultar extraña la referencia a las relaciones entre privación de libertad y tortura: "esta última no toma al cuerpo como mero objeto, lo usa como trámite material que conduce a la destrucción de la psique. No tiene como objetivo el de constreñir al individuo a confesar, sino el de aniquilarlo, negarle sensibilidad y cualidad humana. La tortura representa una forma de anti-terapia: se dirige a hacer pedazos la unidad de la persona... Destrucción y manipulación están respecto a tortura y cárcel como en una ecuación de variables cruzadas" $" 103$. Lo que resulta mucho más evidente cuando el campo de observación está constituido por sujetos privados de libertad precisamente por el modo en que utilizan sus cuerpos.

La irregular aplicación al homosexual de leyes que nacieron con inequívoca vocación represiva -recuérdese la connotación terrorífica que en los ámbitos carcelarios tuvo durante décadas la LVM, conocida como "la Gandula"- guarda estrecha relación con el carácter no monolítico de la valoración social de la homosexualidad y de la reacción institucional frente a ella.

En efecto, la represión de la homosexualidad suscitó, ya en la primera mitad del siglo XX, significativas resistencias. Inicialmente por parte de psicólogos, psiquiatras, médicos (MARAÑÓN, RODRÍGUEZ LAFORA, por ejemplo), que, sin abandonar su valoración negativa del fenómeno, reivindicaron que las políticas dirigidas a su eliminación prescindieran de los castigos penales y se situaran en el plano científico, con el consiguiente despliegue de medios curativos o asistenciales.

Simultáneamente se fue gestando el rechazo social a la satanización del homosexual. En esta línea, la publicación en España del Corydon (1929), donde GIDE reivindica la superioridad del homosexual socrático, abrió un ámbito de controversia, al que se sumaron otras voces relevantes.Muy didáctica resulta, al respecto, la segunda edición (1929) de El Ángel de Sodoma, de HERNÁNDEZ-CATÁ, con prólogo MARAÑÓN y epílogo de JIMÉNEZ DE ASÚA, en la que confluyen literatura, psiquiatría y ciencias penales para proponer alternativas dirigidas a la superación, por parte del homosexual, de la tragedia a que le condena su marginación social ${ }^{104}$.

La biopolítica autoritaria de las dos dictaduras no solo topó con la oposición crítica de minorías de alto nivel cultural; también con la resistencia social a la represión. De suerte que, a pesar de su contundencia, el control institucional fue incapaz de encuadrar disciplinariamente a la población. La penalización de las prácticas homosexuales tuvo múltiples efectos simbólicos, pero no solo no pudo reducirlas, sino que tampoco pudo sustraer la cuestión a la controversia pública.

\footnotetext{
103 GALLO, E., y RUGGIERO, V., Il carcere immateriale, cit., p. 104.

104 TERRADILLOS BASOCO, J.M., Ensayos sobre arte y crimen, op. cit., pp. 67-85.
} 
En el marco de la II República, se registra, sobre todo en los círculos intelectuales de la izquierda política, una progresiva tolerancia frente a la homosexualidad, que no llegó a garantizar la normalización de las prácticas sexuales "diferentes", pero sí colaboró a la visibilización del fenómeno, particularmente potenciada por las vanguardias artísticas y la estética sexualmente ambigua del modernismo ${ }^{105}$.

La dictadura de Franco erigió un muro ideológico frente a la homosexualidad, pero un muro con fisuras incluso en el período inmediatamente postbélico, como consecuencia de la fuerte inclinación de la Falange española, al igual que otros movimientos fascistas europeos, hacia un esteticismo masculino en cuyo marco "tanto el ideal del cuerpo fuerte y sano y la escenificación de una masculinidad superior a la femenina como la camaradería amistosa en el ambiente militar trascendían una y otra vez el límite entre lo sentimental y lo físico"106. Mientras, en el discurso oficial se presentaba la homosexualidad como práctica "desvirilizadora", pues un hombre solo podía tener sexo con mujeres, la estética, basada en el modelo nacionalsocialista, era decididamente homófila ${ }^{107}$.

Simultáneamente, se desarrolló un incipiente movimiento feminista de resistencia, que opuso al ideal franquista de esposa/madre, sumisa al varón, infravalorada y dependiente ${ }^{108}$, la realidad de una mujer que asume su rol de ciudadana titular de derechos en términos de tendencial igualdad. Con el lejano antecedente de La Tribuna (1882), de PARDO BAZÁN, reivindicadora de la mujer como sujeto político y sindical ${ }^{109}$ pero también como persona autónoma que se afirma frente al varón ${ }^{110}$, el feminismo español consolida su andadura en la década de los años veinte.

Con todo, los ámbitos de visibilidad del homosexual quedaron muy recortados por el franquismo ${ }^{111}$, que, en sus últimas fases, recluyó a los invertidos en guetos más o menos recónditos, susceptibles de fácil control policial ${ }^{112}$. Quizá como reflejo de los cambios registrados, a partir de los años cincuenta, tanto en la construcción teórica como en la praxis de la criminología, el poder disciplinario cede terreno al poder de control, y el sistema penal se dirige, más que a la recuperación del condenado por medio de penas/medidas útiles, a la neutralización de los sujetos no útiles. Cambia también la referencia teleológica, que no es ya

105 MIRA NOUSELLES, A., "Modernistas, dandis y pederastas: articulaciones de la homosexualdad en la "edad de plata", en Journal of Iberian and Latin American Studies, 7.1., 2001, p. 65.

${ }^{106}$ ALTMANN, W., "Vicio repugnante en lo social, aberración en lo sexual, perversión en lo psicológico y defecto en lo endocrino. Un ensayo bibliográfico sobre la homosexualidad y los homosexuales bajo la dictadura franquista", op. cit., p. 203.

107 OLMEDA NICOLÁS, F., El látigo y la pluma, op. cit., p. 93..

108 GARCÍA MOYA, M., "Las purgas silenciadas del franquismo y estalinismo", en Hispania Nova. Revista de Historia Contemporánea, 11, 2013, pp. 73-92 (http://hispanianova.rediris.es/11/HN2013.pdf, consulta: 21/05/2020).

109 TERRADILlOS BASOCO, J.M., Ensayos sobre arte y crimen, op.cit., p. 29.

${ }^{110}$ PARDO BAZÁN, E., La Tribuna, $3^{\text {a }}$ ed., Cátedra, Madrid, 1981, p. 232

111 GONZÁLEZ DURO, E., "Psiquiatrización de la marginación”, en Grupos marginados y peligrosidad social (edit. López Linage, J.), Campo Abierto Ediciones, Madrid, 1977, p. 179.

112 CHAMOULEAU, B., Tiran al maricón. Los fantasmas queer de la democracia (1970-1988), op. cit., p. 171. 
la producción de individuos disciplinados, sino la observación y direccionamiento de los colectivos de riesgo ${ }^{113}$.

El elemento esencial de la transición del modelo de disciplina al de control es la supeditación de los objetivos preventivo-especiales, que actúan a través de la inocuización y la reinserción, a la denominada por MELOSSI, en 1966, "la función teatral... representación moral en la que se manifiestan los misterios del bien y del mal específicos de un cierto tejido social...". Receptores de esa teatralización no son, en consecuencia, los más próximos a la tentación de delinquir, sino la mayoría social: "Es esa mayoría a la que es realmente importante controlar, no porque los individuos que la componen tengan la intención o la oportunidad de protagonizar comportamientos criminalizables, sino porque, en su conjunto, podrían llevar a cabo comportamientos desviados o ilícitos, a menudo de naturaleza no penal, que constituirían, aun cuando sólo fuera por su cantidad, un peligro mucho más grave para la estabilidad del orden social, $y$, por tanto, para los intereses y los valores que este garantiza"114.

Es cierto que la débil criminología española de la época seguía anclada en los modelos disciplinarios, pero la realidad política que apuntaba hacia la definitiva inhabilitación de las descalificaciones morales como criterio de exclusión, y hacia la consciencia de que el control resultaba más eficiente que la imposible curación del invertido, llevó a la salida de la homosexualidad del catálogo de supuestos de peligrosidad social -con la Ley 77/1978- y a la definitiva implantación de métodos de prevención situacional, ejercida mediante el "control de las periferias, los ambientes de riesgo, lugares donde se concentran la mayor cantidad de excluidos del sistema productivo", lo que legitima que los sectores más vulnerables de población -en este caso, los homosexuales-, etiquetados como riesgosos, queden sometidos a los programas de exclusión más idóneos ${ }^{115}$.

\section{LA SUPERACIÓN CONSTITUCIONAL}

Los comicios legislativos de 15 de junio de 1977 fueron el marco idóneo para que los partidos políticos concurrentes, y no solo los de la izquierda, convirtieran a la derogación de la LPRS en uno de los leit motiv de la campaña electoral ${ }^{116}$.

La Ley 77/1978, de 26 de diciembre -la Constitución entró en vigor el 29- eliminó del catálogo de supuestos de estado peligroso la realización de los actos de homosexualidad, pero no el ejercicio habitual de la prostitución ni los comportamientos insolentes, brutales o cínicos con notorio menosprecio a las normas de convivencia social. El marco constitucional debería

\footnotetext{
113 DE GIORGI, A., Tolerancia cero: estrategias y prácticas de la sociedad de control, op. cit., pp. 46-51.

114 MELOSSI, D., "Ideología y derecho penal: ¿El garantismo jurídico y la criminología crítica como nuevas ideologías subalternas?”, en Pena y Estado: función simbólica de la pena (dir. Bustos Ramírez, J.), Editorial Jurídica Cono Sur, Santiago de Chile, 1995, p. 62.

115 YOUNG, J., La sociedad “excluyente”. Exclusión social, delito y diferencia en la Modernidad Tardia, Marcial Pons, Madrid, 2003, p. 78.

116 TERRADILlOS BASOCO, J.M., Peligrosidad Social y Estado de derecho, Akal, Madrid, 1981, p. 63.
} 
haberse traducido en el completo alejamiento entre opciones sexuales y Derecho represivo, pero lo cierto es que las categorías punitivas franquistas pudieron, en el nuevo contexto normativo, seguir operando como instrumento de "delimitación de lo social en términos morales" 117 , con la consiguiente posibilidad de inclusión de lo homosexual en el ámbito de lo asocial o amoral.

Finalmente, el CP de 1995 declararía: “1. Quedan derogados:...c) La Ley 16/1970, de 4 de agosto, sobre Peligrosidad y Rehabilitación Social con sus modificaciones posteriores y disposiciones complementarias" (Disposición derogatoria única, $1 \mathrm{c}$ ).

La Ley 52/2007, de 26 de diciembre, por la que se reconocen y amplían derechos y se establecen medidas en favor de quienes padecieron persecución o violencia durante la guerra civil y la dictadura, normalmente conocida como Ley de la Memoria Histórica (en adelante, LMH), constituye el último paso general en el largo proceso de revisión desde la Constitución de los excesos de la dictadura franquista durante y después de la guerra civil.

Ya la Ley 46/1977, de 15 de octubre, de Amnistía, había cercenado las posibilidades de puesta en marcha en España de una justicia "transicional"; y las inevitables transacciones políticas del momento -que algún sector ha calificado de mera "operación cosmética" 118 - se tradujeron en una "ley de punto final", que, sorprendentemente, antecede a cualquier eventual proceso judicial sobre hechos de la época ${ }^{119}$.

Pero la "transición", precisamente por ser tal, no dejó cerradas todas las cuestiones litigiosas surgidas en el pasado inmediato $\mathrm{y}$, ya en período constitucional, seguía resultando imprescindible la reparación de algunos de los frutos de la Guerra civil y la Dictadura más abiertamente incompatibles con el nuevo orden ${ }^{120}$.

El art. 1.1 de la LMH enfatiza la orientación reparatoria y se fija, como objetivo general: "reconocer y ampliar derechos a favor de quienes padecieron persecución o violencia, por razones políticas, ideológicas, o de creencia religiosa, durante la Guerra Civil y la Dictadura, promover su reparación moral y la recuperación de su memoria personal y familiar".

El reconocimiento de un derecho individual a la memoria histórica -una de las más innovadoras aportaciones de la Ley-, no carece de contenido: se desglosa en el derecho a la reparación moral de la víctima y de sus familias; a la recuperación de la memoria personal y familiar; a la

\footnotetext{
${ }^{117}$ CHAMOUlEAU, B., Tiran al maricón. Los fantasmas queer de la democracia (1970-1988), op. cit., p. 142. 118 MUÑOZ CONDE, F., "La transformación jurídica de la dictadura franquista en un Estado de Derecho", en Revista Penal, 22, 2008, p. 71.

119 AGUILAR FERNÁNDEZ, P., "Guerra civil, franquismo y democracia”, en Claves de Razón Práctica, 140, 2004, p. 24.

120 TERRADILlOS BASOCO, J.M., "La revisión del pasado y la Ley de Memoria Histórica”, en Revista Penal, 25, 2010, p. 152 .
} 
declaración general de ilegitimidad de la represión; a reparaciones económicas y, finalmente, al derecho a saber ${ }^{121}$.

Es posible, sin embargo, que el legislador fuese más parco a la hora de dotar de contenido a ese conjunto de derechos que a la hora de proclamarlos.

Ya en mayo de 1995, en desarrollo pionero del programa de reivindicación de la memoria histórica, la Junta de Extremadura inauguró, en lo que fuera edificio central de la prisión de Badajoz, el Museo Extremeño e Iberoamericano de Arte Contemporáneo. Por su parte, la Junta de Andalucía, en noviembre de 2014, declaró a la prisión de Huelva, Lugar de Memoria Histórica. Y en abril de 2018 la Consejería de Presidencia, Administración Local y Memoria Democrática descubrió en sus puertas una placa con el texto: "Para una generación de españoles este establecimiento penitenciario fue símbolo de castigo y exclusión social a quienes decidieron ejercer su libertad de ser y amar de forma diferente. Quede esta placa como reparación de la sociedad democrática a una injusticia histórica en recuerdo de las personas trans y homosexuales que fueron encarceladas y como compromiso de que ninguna generación tendrá que pasar por nada semejante”. Hasta 2018 se había recordado solo a los homosexuales presos hasta 1979. La nueva placa incluye, también, a las personas transexuales.

Más allá de lo simbólico institucional, en el plano de las reparaciones individuales, la Disposición adicional decimoctava (“indemnización a 'ex' presos sociales”) de la Ley 2/2008, de 23 de diciembre, de Presupuestos Generales del Estado para el año 2009 -desarrollada por Real Decreto 710/2009 de 17 de abril-, establece que "Se concederá una indemnización a quienes hubiesen sido objeto de medidas de internamiento por su condición de homosexuales en aplicación de la Ley de 15 de julio de 1954, por la que se modifica la Ley de Vagos y Maleantes de 4 de agosto de 1933, o de la Ley 16/1970, de 4 de agosto, sobre Peligrosidady Rehabilitación Social...” Por su parte, la Ley 17/2012, de 27 de diciembre, de Presupuestos Generales del Estado para el año 2013, en su Disposición adicional trigésima tercera. ("Indemnizaciones por tiempo de prisión y a favor de ex-presos sociales") fija como fecha de finalización del plazo para presentación de solicitudes de estos "beneficios", el 31 de diciembre de 2013.

Solo ciento dieciséis “ex-presos sociales" recibieron una indemnización. Se distribuyeron seiscientos veinticuatro mil euros, esto es, cinco mil trescientos por persona ${ }^{122}$. Del compromiso inicial -crear un fideicomiso con los cuatro millones de euros aprobados para este fin en los Presupuestos Generales del Estado para 2010- se pasó, en la práctica, a indemnizaciones que apenas superaron el quince por ciento ${ }^{123}$.

\footnotetext{
${ }^{121}$ SAUCA CANO, J.M., "El derecho ciudadano a la memoria histórica: concepto y contenido", en Derecho y Memoria Histórica (edit. Martín Pallín, J.A., y Escudero Alday, R.), Trotta, Madrid, 2008, p. 90.

$122 \mathrm{https} / /$ cronicaglobal.elespanol.com/vida/indemnizan-116-homosexuales-mas-mil_65853_102.html, consulta: $21 / 05 / 2020$.

123 http://www.elmundo.es/sociedad/2017/01/03/586a9f5f468aeb321b8b464a.html, consulta: 21/05/2020.
} 
Por otra parte, los internamientos acordados en aplicación de la LPRS constituían a los sujetos a quienes se aplicaban en presos sociales. Pero presos objeto de una represión sexuada específica -semejante a la que sufrieron las mujeres-, que no se produjo con los presos "políticos". Así, las medidas de reparación de los homosexuales, exclusivamente económicas y proporcionales al tiempo de privación de libertad, hicieron tabla rasa de su condición de víctimas especiales de la dictadura. Por ejemplo, la Ley 18/1984, de 8 de junio, que pretende subsanar los ilegales perjuicios causados a "las personas que, debido a su permanencia en prisión por actos de intencionalidad politica, no han podido consolidar o lo han hecho en su mínima cuantía su derecho a todas o algunas de las prestaciones que otorga el sistema de la Seguridad Social", asimila los períodos de prisión a períodos cotizados a la Seguridad Social. Pero como el ámbito personal de tutela queda limitado a los supuestos contemplados en la Ley de Amnistía, es decir, comportamientos políticos en los que difícilmente se pueden subsumir las prácticas homosexuales, los condenados por tales prácticas quedan excluidos de la asimilación, lo que supone tanto como confirmación, en período constitucional, de las consecuencias de una discriminación que tuvo su origen en el franquismo ${ }^{124}$.

En el ámbito civil, en el entendimiento de que la Constitución y, más en concreto, sus artículos 9.2, 10.1 y 14, habían instaurado "un marco de igualdad real en el disfrute de los derechos sin discriminación alguna por razón de sexo, opinión o cualquier otra condición personal o social", que reflejaba la evolución de la realidad social española, "mucho más rica, plural y dinámica que la sociedad en que surge el Código Civil de 1889”, la Ley 13/2005 puso fin “a la prohibición de contraer matrimonio a las parejas del mismo sexo, y garantizarles los plenos derechos y beneficios del matrimonio" (Preámbulo, I y II).

La razonable jerarquía que, en el plano normativo, disfrutan los preceptos, incorporados o no a la Constitución, garantes de la igualdad de las diferentes opciones en materia sexual, de la prohibición de discriminación y del derecho a que los poderes públicos remuevan los obstáculos a la plena participación de todos los ciudadanos en la vida política, económica, cultural y social, no encuentra un reflejo satisfactorio en la convivencia cotidiana.

La Agencia de Derechos Fundamentales de la Unión Europea, en informe fechado en mayo de 2020, ha podido constatar que el colectivo LGTBI sigue soportando niveles "elevados" de discriminación y que el progreso hacia la igualdad, respecto a 2012, es "bajo o ninguno".

El colectivo, que en España alcanza un porcentaje de visibilidad (no ocultación de la condición sexual) superior a la media europea, de $53 \%$, declara que un $42 \%$ de sus integrantes ha sufrido, en el último año, discriminación en el trabajo, la vivienda, la enseñanza, la sanidad o el comercio. La incidencia de los comportamientos discriminadores es distinta según las características de cada modalidad de autonomía sexual: los sufrieron un $63 \%$ de las personas transexuales y un $61 \%$ de las intersexuales, un $45 \%$ de mujeres lesbianas, un $38 \%$ de bisexuales y un $37 \%$ de hombres homosexuales.

124 VALLÉS MUÑÍO, D., "La privación de libertad de los homosexuales en el franquismo y su asimilación al alta en la Seguridad Social”, en IUSLabor, 1, 2017, pp. 6-10. 
La discriminación en el trabajo ha afectado a un 20\%, sin embargo un 60\% de los discriminados, y el porcentaje es alto en relación con lo registrado en la Unión Europea, ha recibido solidaridad y apoyo por parte de los compañeros de trabajo.

Un 8\% de las personas LGTBI ha sufrido un ataque sexual o físico en los últimos cinco años. En la Unión Europea el porcentaje asciende al 11\% ${ }^{125}$.

\section{EPÍLOGO}

En las memorias de BUÑUEL, Jean-Claude CARRIÈRE pone en boca del cineasta las siguientes palabras: "Alguien vino a decirme que un tal M.D., un muchachote vasco, afirmaba que Lorca era homosexual. No podía creerlo. Por aquel entonces en Madrid no se conocía más que a dos o tres pederastas, y nada permitía suponer que Federico lo fuera".

En el ambiente laico e ideológicamente plural de la primera época de la Residencia de Estudiantes, se constata la resiliencia del viejo prejuicio que asocia a la homosexualidad lacras -la pederastia en este caso- que, por ir "naturalmente" unidas a ella, la hacen acreedora de todas las descalificaciones. A la homosexualidad y al homosexual. De modo que el propio Buñuel, en 1922, espeta a su amigo del alma, al que luego reconocería deber "todo", el, entonces, descalificante epíteto de "maricón" 126.

El exabrupto de Buñuel, pródigo repartidor de exabruptos, quedó prontamente superado por la recuperación de su amistad con Lorca. Pero, en la sociedad biempensante de la época, no era la amistad la respuesta más habitual a la homosexualidad. Quizá tampoco hoy. Aunque, ciertamente, el estatus legal actual del colectivo LGTBI, tras desmontar argumentarios excluyentes acientíficos y resistir la disciplina y el control penal sufridos a lo largo de decenios, dista mucho del vigente en 1922.

\section{BIBLIOGRAFÍA}

ACALE SÁNCHEZ, M., "Libertad vigilada", en Comentarios a la reforma penal de 2010 (dir. Álvarez García, F.J., y González Cussac, J.L.), Tirant lo Blanch, Valencia, 2010, pp. 147-158.

AGUILAR FERNÁNDEZ, P., "Guerra civil, franquismo y democracia”, en Claves de Razón Práctica, 140, 2004, pp. 24-33.

ALTMANN, W., "Vicio repugnante en lo social, aberración en lo sexual, perversión en lo psicológico y defecto en lo endocrino. Un ensayo bibliográfico sobre la homosexualidad

\footnotetext{
$125 \mathrm{https}: / / w w w . e l d i a r i o . e s /$ sociedad/personas-LGTBI-Espana-publico-restaurantes_0_1026798015.html, consulta: 21/05/2020.

${ }^{126}$ CARRIÈRE, J-C., y BUÑUEL, L., Mi último suspiro, Debolsillo, Barcelona, 2012, p. 79.
} 
y los homosexuales bajo la dictadura franquista", en Iberoamericana, 22, 2006, pp. 193210.

ARNALTE BARRERA, A., "Galería de invertidos, vida cotidiana de los homosexuales en las cárceles de Franco", en Orientaciones. Revista de las homosexualidades, 7, 2004, pp. 101-112.

BERNALDO DE QUIRÓS, C., y LLANAS AGUINALEDO, J. Mª La Mala Vida en Madrid. Estudio psicosociológico, B. Rodríguez Sierra, Madrid, 1901.

CARRIÈRE, J-C., y BUÑUEL, L., Mi último suspiro, Debolsillo, Barcelona, 2012.

CASTELlANOS SANTAMARÍA, P., Policía integral o policía nacional sindicalista, Imprenta Católica F.G. Vicente, Valladolid, 1939.

CHAMOULEAU, B., Tiran al maricón. Los fantasmas queer de la democracia (1970-1988), Akal, Madrid, 2017.

CLEMINSON, R., "Marginados dentro de la marginación: prostitución masculina e historiografía de la sexualidad (España, 1880-1930)" en Las figuras del desorden. Heterodoxos, proscritos y marginados. Actas del V Congreso de Historia Social de España, (coord. Castillo, S., y Oliver, P.), Siglo XXI, Madrid, 2006, pp. 309-340.

CONDE-PUMPIDO FERREIRO, C., "Aspectos substantivos de la Ley de Peligrosidad y Rehabilitación Social de 4 de agosto de 1970”, en AA.VV., Temas Penales, Universidad de Santiago de Compostela, Santiago de Compostela, 1973, pp. 189-244.

CUELLO CALÓN, E., "Referencias históricas y de derecho comparado sobre la represión de la homosexualidad", en Anuario de Derecho Penal y Ciencias Penales, VII.3, 1954, pp. 498-501.

DE GIORGI, A., Tolerancia cero: estrategias y prácticas de la sociedad de control, Virus Editorial, Barcelona, 2005.

DE MAEZTU, R., Hacia otra España, Imp. y Enc. de Andrés P. Cardenal, Bilbao, 1989 (http://www.memoriadigitalvasca.es/handle/10357/5225, consulta: 21/05/2020).

DÍAZ GARCÍA, E., Pensamiento español en la era de Franco (1939-1975), Tecnos, Madrid, 1983.

DORADO MONTERO, P., Bases para un nuevo Derecho Penal, Gallach, Barcelona 1923.

FAIRÉN GUILLÉN, V., "Prevención y represión desde el punto de vista procesal”, en Anuario de Derecho Penal y Ciencias penales, 1, 1971, pp. 5-52.

FERRAJOLI, L., Derecho y Razón. Teoría del garantismo penal, Trotta, Madrid, 1995. 
FOUCAULT, M., Un caso de parricidio del siglo XIX presentado por Michel Foucault, Tusquets, Barcelona 1976.

FRUTOS CARABIAS, L., "Introducción a la versión española", en Los homosexuales vistos por sí mismos y por sus médicos (edit. Krich, A.M. ) Morata, Madrid, 1966, pp. 3-9.

GALLO, E., y RUGGIERO, V., Il carcere immateriale, Edizioni Sonda, Torino, 1989.

GARCÍA MOYA, M., "Las purgas silenciadas del franquismo y estalinismo", en Hispania Nova. Revista de Historia Contemporánea, 11, 2013, pp. 73-92 (http://hispanianova.rediris.es/11/HN2013.pdf, consulta: 21/05/2020).

GONZÁLEZ DURO, E., "Psiquiatrización de la marginación", en Grupos marginados y peligrosidad social (edit. López Linage, J.), Campo Abierto Ediciones, Madrid, 1977, pp. 174-197.

GONZÁLEZ DURO, E., Los psiquiatras de Franco. Los rojos no estaban locos, Planeta, Madrid, 2008.

HERRERA ORIA, E., Historia de la Educación Española desde el Renacimiento, Veritas, Madrid, 1941.

HIRSCHFELD, M., "El homosexual como sexo intermedio", en Los homosexuales vistos por sí mismos y por sus médicos, (edit. Krich, A. M.), Morata, Madrid, 1966, pp. 177- 197.

JIMÉNEZ DE ASÚA, L., "Epílogo”, a HERNÁNDEZ-CATÁ, A., El Ángel de Sodoma, 2ª ed., Mundo Latino, Madrid, 1929, pp. 239-255.

JIMÉNEZ DE ASÚA, L, “Ley de Vagos y Maleantes. Un ensayo legislativo sobre peligrosidad sin delito", en Revista General de Legislación y Jurisprudencia, 163, 1933, pp. 577-635

JORGE BARREIRO, A., Las medidas de seguridad en el Derecho español, Civitas, Madrid, 1976.

JORGE BARREIRO, A., "Reflexiones sobre la regularización de las medidas de seguridad en el Nuevo Código Penal Español”, en Jueces para la Democracia, 25. 1996, pp. 46-52.

KARL, M., Sodomitas, NOS, Madrid, 1956.

KRICH, A. M., "Prefacio" a Los homosexuales vistos por sí mismos y por sus médicos, (edit. Krich, A. M.), Morata, Madrid, 1966, pp. IX-XV.

LAGUÍA ARRAZOLA, A., "Homosexualidad y delincuencia mentalmente anormal”, en XI Curso Internacional de la Sociedad Internacional de Criminología. Los delincuentes mentalmente anormales. Conferencias y Comunicaciones, (edit., Castro, B.F., y Cobo del Rosal, M.), Universidad de Madrid-Facultad de Derecho, Madrid, 1961-1962, pp. $385-401$. 
LÓPEZ IBOR, J. J., El libro de la vida sexual, Dánae, Barcelona, 1968.

MARAÑÓN, G., Los estados intersexuales en la especie humana, Javier Morata, Madrid, 1929.

MARAÑÓN, G., "Prólogo" a HERNÁNDEZ-CATÁ, A., El Ángel de Sodoma, 2a ed., Mundo Latino, Madrid, 1929, pp. 11-41.

MARAÑÓN, G., La evolución de la sexualidad y los estados intersexuales, Ediciones Arcos, Madrid, 1951.

MARISTANY, L., El gabinete del doctor Lombroso (Delincuencia y fin de siglo en España), Anagrama, Barcelona, 1973.

MELOSSI, D., “Ideología y derecho penal: ¿El garantismo jurídico y la criminología crítica como nuevas ideologías subalternas?", en Pena y Estado: función simbólica de la pena, (dir. Bustos Ramírez, J.), Editorial Jurídica Cono Sur, Santiago de Chile, 1995, pp. 5766.

MIRA NOUSELLES, A., "Modernistas, dandis y pederastas: articulaciones de la homosexualidad en la "edad de plata", en Journal of Iberian and Latin American Studies, 7.1, 2001, pp. 63-75.

MODONA, G. N., "Tecnicismo e scelte politiche nella riforma del codice penale", en Democrazia e Diritto, 4, 1977, pp. 661-684.

MORA GASPAR, V., Al margen de la naturaleza. La persecución de la homosexualidad durante el franquismo. Leyes, terapias y condenas, Debate, Barcelona, 2016.

MUÑOZ CONDE, F., Edmund Mezger y el Derecho penal de su tiempo, $4^{\mathrm{a}}$ ed., Tirant lo Blanch, Valencia, 2003.

MUÑOZ CONDE, F., "La transformación jurídica de la dictadura franquista en un Estado de Derecho", en Revista Penal, 22, 2008, pp. 69-79.

NAVARRO DE PALENCIA, A., Socialismo y Derecho criminal, Reus, Madrid, 1919.

OLESA MUÑIDO, F. F., Las medidas de seguridad, Bosch, Barcelona, 1951.

OLMEDA NICOLÁS, F., El látigo y la pluma, Editor Digital: Polifemo 7, Madrid, 2013 (http://assets.espapdf.com, consulta: 21/05/2020).

PARDO BAZÁN, E., La Tribuna, 3ª ed., Cátedra, Madrid, 1981.

PEMÁN, J. Ma , El hecho y la idea de la Unión Patriótica, Imprenta Artística Sáez Hermanos, Madrid, 1929.

PEMARTÍN, J., Los valores históricos de la Dictadura española, $2^{\mathrm{a}}$ ed., Publicaciones de la Junta de Propaganda Patriótica y Ciudadana, Madrid, 1929. 
PÉREZ SALMÓN, C., "Sanchís Banús y el psicoanálisis: historia de una relación", en Revista de Historia de la Psicología, 3-4, 2003, pp. 519-526.

PINILLOS, J. L., "Marañón, transgresor de su época”, en La evolución de la sexualidad y los estados intersexuales, (edit. Botella Llusiá, J., y Fernández de Molina, A.), Ediciones Díaz de Santos, Madrid, 1997, pp. 61 a 64.

PORTILLA CONTRERAS, G., "Colaboración de la Iglesia católica en la represión penal de la masonería y el comunismo durante el franquismo", en Revista Penal. México, 3, 2012, pp. 193-201.

QUINTERO OLIVARES, G., Locos y culpables, Aranzadi, Pamplona, 1999.

QUIROGA FERNÁNDEZ DE SOTO, A., "Educación para la ciudadanía autoritaria. La nacionalización de los jóvenes en la dictadura de Primo de Rivera”, en Historia de la Educación. Revista Interuniversitaria, 27, 2008, pp. 87-104.

QUIROGA FERNÁNDEZ DE SOTO, A., Haciendo españoles: la nacionalización de las masas en la Dictadura de Primo de Rivera (1923-1930), Centro de Estudios Políticos y Constitucionales, Madrid, 2008.

RÖDER, C.D.A., Las doctrinas fundamentales reinantes sobre el delito y la pena en sus interiores contradicciones. Ensayo crítico preparatorio para la renovación del Derecho Penal, $3^{\mathrm{a}}$ ed., Librería de Victoriano Suárez, Madrid, 1876.

SABATER TOMÁS, A., Gamberros, homosexuales, vagos y maleantes (Estudio jurídicosociológico), Editorial Hispano Europea, Barcelona, 1962.

SÁNCHEZ SÁNCHEZ, E. M "El auge del turismo europeo en la España de los años sesenta", en Arbor, CLXX.669, 2001, pp. 201-224.

SAUCA CANO, J. M., "El derecho ciudadano a la memoria histórica: concepto y contenido", en Derecho y Memoria Histórica (edit. Martín Pallín, J.A., y Escudero Alday, R.), Trotta, Madrid, 2008, pp. 73-104.

SILVA BARRERA, E., y MACÍAS SANTIAGO, S., Las fosas de Franco, los republicanos que el dictador dejó en las cunetas, Temas de Hoy, Madrid, 2003.

SOSA MACHÍN, M. A., Viaje al centro de la infamia, Anroart, Las Palmas de Gran Canaria, 2006.

TAMAMES, R., La República. La Era de Franco, Alianza Editorial-Alfaguara, Madrid, 1973.

TERRADILLOS BASOCO, J. M., "Un supuesto de estado peligroso: la vagancia habitual”, en Materiales, 10, 1978, pp. 75-92. 
TERRADILlOS BASOCO, J. M., Regulación española de las medidas de seguridad y garantías individuales, Editorial de la Universidad Complutense de Madrid, Madrid, 1980 .

TERRADILlOS BASOCO, J. M., Peligrosidad Social y Estado de derecho, Akal, Madrid, 1981.

TERRADILLOS BASOCO, J. M. "Capítulo XI. Las medidas de seguridad”, en MAPELLI CAFFARENA, B., y TERRADILLOS BASOCO, J.M., Las consecuencias jurídicas del delito, $3^{\mathrm{a}}$ ed., Civitas, Madrid, 1996.

TERRADILLOS BASOCO, J. M., "Vigencia del derecho penal del krausismo", en AA.VV., Jornadas Homenaje a Giner de los Ríos, Universidad de Jaén, Jaén, 1999, pp. 25 a 45.

TERRADILLOS BASOCO, J. M., "La revisión del pasado y la Ley de Memoria Histórica”, en Revista Penal, 25, 2010, pp. 151 a 166.

TERRADILLOS BASOCO, J. M., "Construcción y enseñanza del Derecho penal del Nuevo Estado. Los orígenes del Código Penal de 1944", en Modelos de Derecho del Trabajo y cultura de los juristas, (coord. Baylos Grau, A.), Bomarzo, Albacete, 2014, 201-221.

TERRADILLOS BASOCO, J.M., Ensayos sobre arte y crimen, Tirant lo Blanch, Valencia, 2020.

TOMÁS Y VALIENTE, F., "El crimen y el pecado contra natura”, en Orientaciones. Revista de homosexualidades, 1, 2001, pp. 105 a128.

TUÑÓN DE LARA, M., La II República.1, Siglo XXI, Madrid, 1976.

UGARTE PÉREZ, F. J., "Las bases ideológicas de la represión”; en Una discriminación universal. La homosexualidad bajo el franquismo y la transición (Ugarte Pérez, F. J., edit.), Egales Editorial, Barcelona-Madrid, 2008, pp. 49-78.

VALLEJO NÁGERA, A., La asexualización de los psicópatas, Medicina, Madrid, 1934.

VALLEJO NÁGERA, A., Eugenesia de la Hispanidad y regeneración de la raza, Editorial Española, Burgos, 1937.

VALLÉS MUÑíO, D., "La privación de libertad de los homosexuales en el franquismo y su asimilación al alta en la Seguridad Social”, en IUSLabor, 1, 2017, pp. 1-13.

VÁZQUEZ GARCÍA, F. J., La invención del racismo. Nacimiento de la biopolítica en España 1600-1940, Akal, Madrid, 2009.

VÁZQUEZ GARCÍA, F. J., y CLEMINSON, R., Los invisibles. Una historia de la homosexualidad masculina en España, 1850-1939, Comares, Granada, 2011. 
YOUNG, J., 2003, La sociedad "excluyente". Exclusión social, delito y diferencia en la Modernidad Tardía, Marcial Pons, Madrid. 